Environmental Microbiology

September 2009, Volume 11, Issue 9, Pages 2446 - 2462

http://dx.doi.org/10.1111/j.1462-2920.2009.01976.x

(c) 2009 Society for Applied Microbiology and Wiley - Blackwell

Publishing Ltd.
Archimer, archive institutionnelle de l'Ifremer http://www.ifremer.fr/docelec/

The definitive version is available at http://www3.interscience.wiley.com/

\title{
Archaeal communities associated with shallow to deep subseafloor sediments of the New Caledonia Basin
}

\author{
Erwan G. Roussel ${ }^{1, *}, \#, 3$, Anne-Laure Sauvadet ${ }^{1,3}$, Carine Chaduteau ${ }^{2}$, Yves Fouquet ${ }^{2}$, Jean-Luc
} Charlou $^{2}$, Daniel Prieur ${ }^{1}$, and Marie-Anne Cambon Bonavita ${ }^{1}$

\author{
${ }^{1}$ Laboratoire de Microbiologie des Environnements Extrêmes, UMR 6197, Université de Bretagne Occidentale, \\ Ifremer, CNRS, Institut Universitaire Européen de la Mer, 29280 Plouzané, France. \\ ${ }^{2}$ Département Géosciences Marines, Ifremer, Centre de Brest, 29280 Plouzané, France. \\ ${ }^{3}$ Equal contribution \\ \# Present address: School of Earth and Ocean Sciences, Cardiff University, Main Building, Park Place, Cardiff, \\ Wales, UK \\ *: Corresponding author : E. Roussel, Tel. (+44) 292087 4488; Fax (+44) 292087 4326, email address : \\ RousselEG@cardiff.ac.uk
}

\begin{abstract}
:
The distribution of the archaeal communities in deep subseafloor sediments [0-36 $\mathrm{m}$ below the seafloor (mbsf)] from the New Caledonia and Fairway Basins was investigated using DNA- and RNAderived 16S rRNA clone libraries, functional genes and denaturing gradient gel electrophoresis (DGGE). A new method, Co-Migration DGGE (CM-DGGE), was developed to access selectively the active archaeal diversity. Prokaryotic cell abundances at the open-ocean sites were on average 3.5 times lower than at a site under terrestrial influence. The sediment surface archaeal community (0$1.5 \mathrm{mbsf}$ ) was characterized by active Marine Group 1 (MG-1) Archaea that co-occurred with ammonia monooxygenase gene (amoA) sequences affiliated to a group of uncultured sedimentary Crenarchaeota. However, the anoxic subsurface methane-poor sediments (below $1.5 \mathrm{mbsf}$ ) were dominated by less active archaeal communities, such as the Thermoplasmatales, Marine Benthic Group D and other lineages probably involved in the methane cycle (Methanosarcinales, ANME-2 and DSAG/MBG-B). Moreover, the archaeal diversity of some sediment layers was restricted to only one lineage (Uncultured Euryarchaeota, DHVE6, MBG-B, MG-1 and SAGMEG). Sequences forming two clusters within the Thermococcales order were also present in these cold subseafloor sediments, suggesting that these uncultured putative thermophilic archaeal communities might have originated from a different environment. This study shows a transition between surface and subsurface sediment archaeal communities.
\end{abstract}

\section{Introduction}

The sub-seafloor biosphere may comprise as much as two thirds of Earth's total prokaryotic biomass (Whitman et al., 1998) and extends to at least 1626 meters below the seafloor (mbsf) (Roussel et al., 2008). Ubiquitous microbial communities present in the sub-seafloor play an important role in global biochemical cycles (e.g. D'Hondt et al., 2004). The prokaryotic cell density drastically decreases with depth and decreasing available energy supply due to reduction in efficient electron acceptors and bioavailable organic carbon sources (Parkes et al., 2000; Schippers et al., 2005). However, local increases in cell density 
occur in response to specific geochemical and lithological conditions (D'Hondt et al., 2004; Parkes et al., 2005; Sørensen and Teske, 2006).

The boundary between surface and subsurface could be defined as a change of the microbial community composition, shifting from surface (e.g. the water column) to deep subsurface communities (Teske and Sørensen, 2008). Moreover, microbial metabolic processes in marine sediments are generally stratified according to the sequential consumption of electron acceptors diffusing into sediments from the overlying seawater. Oxygen, the main electron acceptor in surface sediment, is rapidly depleted, followed by nitrate and manganese (Froelich et al., 1979). However, in deeper anoxic sediments, sulfate reduction and methanogenesis may represent the main metabolic processes in the deep sub-seafloor (D'Hondt et al., 2002; D'Hondt et al., 2004; Parkes et al., 2005). Organic rich coastal sediments, under terrestrial influence, harbor higher microbial densities and activities compared to open-ocean sediments (D'Hondt et al., 2004). Hence, there appears to be a correlation between the origin of the organic matter and biochemical processes, such as methanogenesis (Sivan et al., 2007). Active archaeal communities, involved in biochemical cycles such as methane cycling at depth, could represent a significant fraction of the microbial community of the deep marine subsurface (Biddle et al., 2006; Sørensen and Teske, 2006; Lipp et al., 2008).

The distribution and metabolisms of the sub-seafloor microbial communities are mostly understood through culture-independent techniques (e.g. Newberry et al., 2004; Parkes et al., 2005; Biddle et al., 2006; Fry et al., 2006; Sørensen and Teske, 2006; Biddle et al., 2008), since most of these prokaryotes do not have a closely related cultured relative. In shallow marine sediments, DNA-based molecular approaches are strongly biased as up to 90\% of the total DNA is extra cellular (Danovaro et al., 1999; Dell'Anno and Danovaro, 2005), resulting in an inability to distinguish between living and dead microbial communities (Dell'Anno and Corinaldesi, 2004; Damste and Coolen, 2006). In order to target metabolically active communities, to correlate their phylogeny with variable environmental factors, fluorescent in situ hybridization has commonly been used (e.g. Treude et al., 2005; Biddle et 
Roussel et al.

Archaeal communities in subseafloor sediments

al., 2006). However this approach does not provide an overall picture of the active microbial communities. As rRNA has a rapid turnover (Kemp et al., 1993; Kerkhof and Ward, 1993; Kramer and Singleton, 1993; Danovaro et al., 1999), extractable archaeal rRNA can be used to target the active cells from subsurface sediments (Lloyd et al., 2006; Sørensen and Teske, 2006; Roussel et al., 2009).

The current study investigates some of the spatial and abiotic variables that could possibly control the archaeal community distribution and activities in deep-sea sediments. The analysis of the archaeal diversity and community structures was performed on surface and subsurface sediments from the New-Caledonia and Fairway Basins, with different terrestrial influences, using denaturant gradient gel electrophoresis (DGGE) and cloning PCR-amplified phylogenetic and functional genes. The active fraction of the archaeal community in deepsea sediments was also assessed by a new molecular approach based on DGGE.

\section{Results and discussion}

\section{Site description and total prokaryotic count depth profiles}

The sediment samples were collected from six sites in the New Caledonia and Fairway basins during the Oceanographic cruise ZoNéCo 12 in February 2006 (Fig. 1). Site MD063019 sediments, located in a canyon deriving a substantial amount of terrigenous matter from New Caledonia, comprised a succession of terrigenous sequences composed of dark carbonate clay interspaced with sands (Foucher et al., 2006). Moreover, MD06-3019 sediments had higher contents of minerals from a probable detrital origin such as quartz, chlorite, kaolinite, montmorillonnite, halite and albite, than MD06-3018 sediments, which displayed higher contents of calcite (data not shown). In contrast with site MD06-3019, site MD06-3018 sediments were situated in an open-ocean context, characterized by homogeneous sediment facies composed of foraminiferal clay (Foucher et al., 2006). In the Fairway Basin, sites MD06-3022, MD06-3026, MD06-3027 and MD06-3028 sediments were also located in an open-ocean context. Site MD06-3027 represented a reference zone, in contrast with MD06-3022 and MD06-3028 where the sedimentary sequence was pierced by 
109 a diapir (see supplementary material, Fig. S1) and showed an extensive faulting in the 110 sedimentary cover which could be the consequence of gas migration through the sediment 111 cover (Auzende et al., 2000).

112 On the whole, the prokaryotic cell counts were within the limits of the general depth 113 distribution model (Parkes et al., 2000), although the distribution at site MD06-3019 was 114 more heterogeneous than at the open-ocean sites, fluctuating between the lowest and 115 highest prediction limits (Fig. 2). Moreover, the low cell number, between 7.5 mbsf and 10.5 116 mbsf at site MD06-3019, was correlated with the occurrence of driftwood in the sediment. 117 Therefore, as the core lithology comprised a succession of terrigenous sequences, the 118 heterogeneous prokaryotic cell number distribution and methane depth profile might be related to the strong erosion events of New Caledonia. Although the prokaryotic abundances

120 at the open-ocean sites (MD06-3022, MD06-3026 and MD06-3028) were 3.5 times lower 121 than at the site under terrestrial influence (MD06-3019), no correlation was found between 122 prokaryotic counts and biogeochemical data (Fig. 2). However the low cell numbers and 123 methane content in the Fairway Basin sediments are consistent with the general depth 124 distribution of methane and prokaryotic cells in open-ocean sub-seafloor sediments, 125 presumably reflecting the lower inputs of organic carbon compared with the site under terrigenous influence (Wellsbury et al., 2002; D'Hondt et al., 2004).

\section{Archaeal community structure}

128 Co-Migration DGGE (CM-DGGE). One of the most revealing questions, in sub-seafloor 129 studies, is discriminating and identifying active and living from the dead or quiescent 130 microbial communities. Nucleic acid-based molecular analyses of deep sub-seafloor 131 microbial communities are limited, as sediment samples are usually characterized by low 132 biomass, limited material and the presence of PCR inhibitors (Webster et al., 2003). 133 Fingerprinting techniques, such as DGGE, are recommended for describing the microbial 134 community structures, as a large number of samples can be analyzed (for review, see 135 Smalla et al., 2007). However, as DGGE analyses can be biased by gel variations (e.g. 
Roussel et al.

Archaeal communities in subseafloor sediments

136 Ferrari and Hollibaugh, 1999; Nunan et al., 2005), running intra-lane standards enhances

137 sample-to-sample comparisons (Muyzer, 1999; Neufeld and Mohn, 2005). Here, we developed a new fingerprinting approach based on DGGE and named Co-Migration DGGE (CM-DGGE, see experimental procedures), adapting the use of different terminally labelled fluorescent PCR products, to compare simultaneously the DNA- and RNA-derived microbial community in deep-sea sediments. As the use of labelled primers improves the sensitivity and specificity of DGGE fingerprint detection (Neufeld and Mohn, 2005), it is possible to use rRNA to detect minor archaeal activities, such as the Thermococcales Group 1 (TG-1) at site MD06-3019 (see supplementary material, Fig. S6). Moreover, this technique is also time saving and minimizes the problems of gel handling and staining.

Cluster analysis of DGGE profiles. All the DNA-derived 16S rRNA PCR products from all depths were screened by DGGE prior cloning, in order to select the depths with the most representative archaeal phylogenetic distribution for each core (Webster et al., 2003), and to assess the archaeal community structures. As the degree of separation between DGGE fragments decreases with size due to the melting of multiple melting domains in the larger fragments (Myers, 1988; Sheffield et al., 1989), two sets of primers (A344f ${ }^{\mathrm{GC}}-\mathrm{A} 915 \mathrm{r}$ and SafPARCH 519r) and gel conditions were optimized in order to obtain different scales of band discrimination (Roussel et al., unpublished data). However, the PCR surveys of archaeal communities using the Saf-PARCH 519r primer set were probably less biased than with $\mathrm{A} 344 \mathrm{f}^{\mathrm{GC}}-\mathrm{A} 915 \mathrm{r}$ primer set, as there is a lower number of primer mismatches with specific subsurface and hydrothermal vent archaeal sequences (Teske and Sørensen, 2008). The resulting dendrogram of DGGE patterns, using Saf-PARCH 519r, displayed two major clusters (see supplementary material, Fig. S2C). The Cluster A depths ranged from 0 to 1.5 mbsf, except for two samples (7.5 and $9 \mathrm{mbsf})$ and had fragments exclusively affiliated to

160 MG-1, whereas cluster B was composed of fragments related to 6 different phylotypes (Fig.

161 S2B, Rice cluster V, Thermoplasmatales, MBG-D, SAGMEG, unclassified Euryarchaeota).

162 Statistical analyses of the clone libraries. According to the results of the DGGE screening, 163 twenty five different clone libraries were constructed, representing a total of 771 sequences 
164 (Fig. 3). Whole 16S rRNA sequences, derived from RNA and DNA, were assigned to 71

165 OTUs based on a 95\% genus level of phylotype differentiation (Schloss and Handelsman, 166 2004). Amplifiable DNA was obtained from all depths, and 1 to 13 OTUs were respectively assigned per clone library. The DNA-derived clone libraries were named DNAxTy, where " $x$ " represents the core number and "y" the depth in centimetres of the clone library (Fig. 3). Amplifiable RNA was only obtained above $1.5 \mathrm{mbsf}$ and was not detected at any other depth (Fig. 5 and S6). Thus, two RNA-derived clone libraries, named RNA18T150 (MD06-3018, 1.5 mbsf) and RNA19T150 (MD06-3019, 1.5 mbsf), were respectively assigned with 27 OTUs and 5 OTUs. The coverage values for the 16S rRNA gene clone libraries ranged from 18 to 100\% (Fig. 3). Rarefaction curves were strongly curvilinear for all clone libraries attesting adequate sampling, except for DNA19T150 and DNA19T4 as a result of strong intra-lineage diversities (see supplementary material, Fig. S3).

The archaeal diversity of the seawater clone library (Fig. 3) was significantly different from all 177 sediment clone libraries $(P<0.01)$, suggesting that the detected Archaea are marine 178 sediment communities. Moreover, differences between all DNA-derived clone library diversity 179 indices $\left(F_{S T}\right.$ and the exact test method) were statistically significant $(P<0.01)$ except between 13 clone libraries distributed among three groups, as described in figure 3 . The clone libraries of each group were from similar lineage distributions and matched the cluster 182 analysis of DGGE band patterns, except for DNA28T450 (Fig. 3 and S2). Both the cluster 183 analysis of DGGE band patterns and the distribution of archaeal lineages in clone libraries 184 showed distinct phylogenetical archaeal communities (except for the MG-1 lineage) either restricted to surface ( 0 to $1.5 \mathrm{mbsf}$ ) or to subsurface (below $1.5 \mathrm{mbsf}$ ) sediment horizon (Fig. 3 and S2) suggesting that these archaeal communities could be adapted to specific sedimentary environmental conditions.

Archaeal diversity and metabolic activity: from the sediment surface to the subsurface

189 Sediment surface. The sediment surface archaeal communities of all clone libraries and 190 DGGE community structures above $1.5 \mathrm{mbsf}$ were exclusively dominated by crenarchaeal 
Roussel et al.

Archaeal communities in subseafloor sediments

191

192

193

194

195

196

197

198

199

200

201

202

203

204

205

206

207

208

209

210

211

212

213

214

215

216

217

218

phylotypes related to Marine Group I (MG-1; Fig. 3 and S2). The MG-1 diversity was high (Fig. 4), covering more than five subclades ( $\alpha, \beta, \varepsilon, \xi$ and $\eta)$ and only related to sequences from deep marine sediments (Newberry et al., 2004; Sørensen et al., 2004; Teske and Sørensen, 2008). MG-1 Archaea, identified as aerobic autotrophic ammonia oxidizers (Francis et al., 2005; Könneke et al., 2005; Hallam et al., 2006), are commonly found in seawater and marine sediments, forming several phylogenetic clusters with currently two cultured relatives (Preston et al., 1996; Könneke et al., 2005). Moreover, based on the analysis of the first sequenced genome of a cultured relative (Crenarchaeum symbiosum), the MG-1 were recently proposed as a novel archaeal phylum named Thaumarchaeota (Brochier-Armanet et al., 2008). The seawater archaeal diversity, in the CTDIl clone library, was exclusively composed of sequences related to marine groups, such as MG-1 (95\%), MG-2 (3\%) and MG-3 (2\%) (Fig. 3). However, only two sequences (DNA19T150), out of 673 rRNA gene sequences from sediment samples, matched with sequences from the seawater clone library (Fig. 4), and amoA genes related to seawater phylotypes were not detected (Fig. 6), which suggests that contamination of the sediment by seawater was negligible. As the MG-1 phylotypes retrieved in the sediments were different from those found in the oxic seawater, specific MG-1 subclades could be adapted to sedimentary suboxic conditions (Teske and Sørensen, 2008).

The active fraction of the archaeal community was assessed by Co-Migration DGGE (CMDGGE) analysis of reverse-transcribed and PCR-amplified rRNA and compared to the DNAderived archaeal community. By using the same primer sets and gel conditions as for the previous DGGE analyses, we showed that the archaeal communities were most active between 0 to $1.5 \mathrm{mbsf}$, as no rRNA was detected below $1.5 \mathrm{mbsf}$ (Fig. 5 and S6), and that they were composed of MG-1 Archaea. Congruently, the two RNA-derived libraries (RNA18T150 and RNA19T150) were dominated by sequences related to the same MG-1 sequences as the DNA-derived libraries (Fig. 4) demonstrating that these sediment surface MG-1 communities were active. Moreover, insignificant $F_{S T}$ and $P$ tests $(P<0.01)$ suggested that the sequences from the DNA19T0, DNA19T2, DNA19T4, RNA18T150 and RNA19T150 

clone libraries were from similar lineage distributions and were indistinguishable from the combined communities. However, although the molecular techniques (reverse transcription, PCR and cloning), used to build clone libraries, are known to be inherently biased (Suzuki and Giovannoni, 1996; von Wintzingerode et al., 1997), significant differences in lineage distribution were detected between the RNA and DNA derived libraries at the same depth (RNA18T150, RNA19T150, DNA18T150 and DNA19T150). The ratios between the 16S rRNA gene and 16S rRNA per cell have been reported to be proportional to the metabolic activity of the cells (Dell'Anno et al., 1998), the rRNA content per cell increasing with metabolic activity. As the MG-1 lineage was detected in RNA18T150 and RNA19T150 libraries, whereas absent in DNA18T150 and DNA19T150 libraries, we suggest that the sediments at 1.5 mbsf could have low cell concentrations of very active MG-1 lineage. As MG-1 are putative ammonia-oxidizing Archaea, amplifications of the amoA gene, using archaeal amoA primers (Francis et al., 2005), were performed in order to confirm the occurrence of ammonia-oxidizing Archaea (AOA) in deep marine sediments at sites MD063018 and 3019. Archaeal amoA gene was only detected between the sediment surface and $1.5 \mathrm{mbsf}$. Moreover, to investigate the amoA gene diversity, two archaeal amoA libraries $(n=$ 40 , coverage $=83 \%$ ) were analyzed. These libraries were exclusively composed of $635-b p$ length sequences related to uncultured Crenarchaeota (Fig. 6). These sequences formed 15 OTUs (based on a $2 \%$ cut-off) grouping in a distinct phylogenetic group of sequences from sediments (Francis et al., 2005). However, no amoA sequences related to water column Archaea were detected (Francis et al., 2005) (Fig. 6), suggesting that amoA sequences 240 retrieved were from archaeal communities adapted to sedimentary environments. Moreover, $241 a m o A$ genes related to the sediment cluster were only retrieved at the depths where MG-1 242 rRNA genes were detected. Altogether, these evidences suggest that ammonia-oxidizing 243 could be one of the main archaeal activities at the sediment surface.

244 Subseafloor MG-1 Archaea were also detected at some sites below 1.5 mbsf characterized 245 by an extensive faulting in the sedimentary cover (MD-3026 and 3028; Fig. 3). These sub246 surface MG-1 communities were phylogenetically related to the MG-1 Archaea found at the 
Roussel et al.

Archaeal communities in subseafloor sediments

sediment surface horizon, and amoA genes related to MG-1 were only detected at depths containing MG-1 rRNA genes. Therefore, these communities might be fuelled by ammonium rich fluids originating either from seawater intrusion or from fluid advection from depth. However, no RNA was detected from these depths, suggesting that sub-surface MG-1 are less active or less abundant than the surface communities.

Sediment subsurface. The sub-surface archaeal community, restricted to depths below 1.5 mbsf, was composed of typical sub-seafloor lineages (Fig. 3, S4 and S5, MBG-B, MBG-D, MCG and SAGMEG; for review, see Teske and Sørensen, 2008) usually detected in subsurface sediments and methane-rich environments (Bidle et al., 1999; Inagaki et al., 2003; Newberry et al., 2004; Sørensen et al., 2004; Parkes et al., 2005; Inagaki et al., 2006b; Sørensen and Teske, 2006). A majority of sequences were related to uncultured environmental sequences from these environments (Fig. S4 and S5, highest similarity to pure culture, 99\%). The sediment-derived clone library diversities were very heterogeneous, either strongly dominated by sequences related to Euryarchaeota or by sequences related to Crenarchaeota (Fig. 3). Overall, euryarchaeal lineages represented less than $1 \%$ of the clone libraries from surface sediments (0 to $1.5 \mathrm{mbsf}$ ), whereas below they represented $59 \%$ (Fig. 3). The whole Euryarchaeota phylogenetic diversity was high, representing a total of 10 different lineages (Fig. 3 and S4): Methanococcoides, Novel Methanosarcinales group 1 (NMG-1), Methanosaeta, ANME-2, Thermoplasmatales, Marine Benthic Group D (MBG-D), Deep-Sea Hydrothermal Vent Euryarchaeotal Group 6 (DHVE6), South African Gold Mine Euryarchaeotic Group (SAGMEG), Thermococcales and Uncultured Euryarchaeota (for review see Teske and Sørensen, 2008). Sequences related to the very ubiquitous Thermoplasmatales and MBG-D lineages were found in $44 \%$ of the libraries, representing $26 \%$ of the clones in the libraries below $1.5 \mathrm{mbsf}$ (Fig. 3), suggesting that these lineages could be shallow sediment subsurface-dwelling Archaea (for review see Teske and Sørensen, 2008). The crenarchaeal sequences, detected below $1.5 \mathrm{mbsf}$, clustered into the Miscellaneous Crenarchaeotic Group (MCG) $(<1 \%)$ and the Marine Benthic Group B (MBGB, also called DSAG) lineages (15\%) (Fig. 3, Fig. S2 and S5). MCG Archaea are very 
Roussel et al.

275 ubiquitous in sediment subsurface environments and are thought to be heterotrophic 276 anaerobes utilizing complex organic substrates (Teske and Sørensen, 2008; Fry et al, 2008). 277 Although the small number of sequences related to MCG Archaea retrieved from the New 278 Caledonia and Fairway Basins sediments could be the result of the low organic matter 279 concentrations of these sediments, it is more likely to be the consequence of a primer-related 280 bias, as the primer A344f contains a high number of mismatches with most of the known 281 MCG 16S rRNA genes (Teske and Sørensen, 2008). The archaeal diversity of some 282 sediment layers at different sites was restricted to only one lineage (Fig. 3, Uncultured 283 Euryarchaeota, DHVE6, MBG-B, MG-1 and SAGMEG). Moreover, uncultured 284 Euryarchaeota, DHVE6 and SAGMEG were not detected in any other sediment samples, 285 suggesting that these Archaea may have been selected by specific environmental conditions. 286 However, no archaeal rRNA was retrieved below $1.5 \mathrm{mbsf}$, presumably being below the 287 detection limit (Fig. S6), suggesting that these probably less active deep subseafloor 288 archaeal communities are adapted to these low energy and organic carbon availability 289 environments (D'Hondt et al., 2002; Valentine, 2007).

290 Sulfate reduction and methane cycling activities widely occur in deep marine sediments 291 (D'Hondt et al., 2002; D'Hondt et al., 2004; Parkes et al., 2005; Biddle et al., 2006; Sørensen 292 and Teske, 2006; Webster et al., 2008). At site MD06-3019, sodium ( $r=0.919 ; P<0.0001)$ 293 and chloride $(r=0.774 ; P<0.0001)$ concentrations increased, whereas sulfate $(r=-0.913 ; P$ 294 $<0.0001)$ and calcium $(r=-0.931 ; P<0.0001)$ concentrations decreased with increasing 295 depth (Fig. 2). Although sulfate concentrations decreased with increasing depth at all sites, 296 suggesting the occurrence of sulfate-reducing prokaryotes, no genes encoding for the 297 dissimilatory sulfate reductase ( $d s r$ ) were detected (data not shown), probably resulting from 298 a too low number of sulfate-reducing bacteria. Methane was the only volatile hydrocarbon 299 detected from all sites and co-occurred with relatively high concentration of sulphate (Fig. 2). 300 Though concentrations at all sites were very low, the increase in methane concentrations at 301 sites MD06-3022 ( $r=0.996 ; P<0.001)$, MD06-3026 $(r=0.881 ; P<0.05)$ and MD06-3028 $(r$ 
$=0.999 ; \mathrm{P}<0.0001)$ was correlated with increasing depth (Fig. 2), suggesting the

303 occurrence of methanogenesis. Remarkably, although 16S rRNA gene sequences related to 304 methanogenic and methanotrophic Archaea are very rarely detected in deep sub-seafloor 305 sediments (Parkes et al., 2005), putative methane cycling communities represented almost $4 \%$ of the libraries below 1.5 mbsf (Fig. 3). A large proportion of these sequences (44\%) were related to the Methanococcoides lineage, a methylotrophic methanogen (Singh et al.,

308 2005). The methanogens utilizing $C 1$ compounds usually dominate the marine methanogens 309 within the zone of sulfate reduction, since sulfate reducing bacteria (SRB) do not compete for 310 the same substrates (Purdy et al., 2003). Moreover, two sequences related to Novel 311 Methanosarcinales group 1 (NMG-1), a new uncultured phylotype in the 312 Methanosarcinaceae family (Roussel et al., 2009) (see supplementary material, Fig. S4), 313 were retrieved from open-ocean sites (DNA19T150 and DNA22T150). These sequences 314 grouped with environmental clones (highest similarity to pure culture, $96 \%$ to Methanolobus 315 oregonensis) from a sulfide rich spring (Elshahed et al., 2004) and from estuary sediments 316 (Purdy et al., 2002; Roussel et al., 2009). Interestingly, although Methanosaeta Archaea are 317 acetoclastic methanogens that can be out-competed by SRBs in the sulfate reduction zone 318 (for review, see Muyzer and Stams, 2008), 16S rRNA sequences related to this putative 319 methanogenic lineage were detected in sulfate rich sediments at the open-ocean sites (Fig. 3 and S4). Theoretically competitive prokaryotic activities, such as sulfate reduction and 321 methanogenesis, seem to co-occur at the same sediment horizons in several other deeper 322 subseafloor sediments (D'Hondt et al., 2004; Parkes et al., 2005; Webster et al., 2008), 323 suggesting that the in-situ environmental conditions may strongly modify the interactions 324 between these metabolic pathways (D'Hondt et al., 2004; Webster et al., 2008). Moreover, 325 two sequences related to ANME-2 Archaea, a putative anaerobic methane oxidizer that is 326 usually found in association with SRBs (Hinrichs et al., 1999; Boetius et al., 2000) and rarely 327 detected in deeper subsurface sediments (Roussel et al., 2008), were detected (Fig. 3 and 328 S4), suggesting that methane and sulphate concentrations in these open-ocean sediments 329 might be sufficient to enable a detectable ANME biomass to develop. Moreover, MBG-B 
Archaea, a lineage that may possibly benefit directly or indirectly from anaerobic methane oxidization (AOM) (Biddle et al., 2006; Sørensen and Teske, 2006; Teske and Sørensen, 2008), are numerous in clone libraries below $1.5 \mathrm{mbsf}$ (15\%). The MBG-B Archaea are limited to marine environments such as hydrothermal vents (Takai and Horikoshi, 1999), cold seeps (Lloyd et al., 2006) and subsurface sediments (Biddle et al., 2006; Sørensen and Teske, 2006). However, although no methyl-coenzyme M reductase ( $m c r)$ genes were retrieved (data not shown), the detection of putative methanotrophs, acetoclastic methanogens and methylotrophic methanogens at two open-ocean sites, suggests that low methane cycling rates may comprise a proportion of the archaeal activities at these sites.

Contamination by exogenous DNA was of particular concern (see Experimental Procedures), and as all contamination controls were negative, the detection of rarely detected sub-seafloor sediment lineages, such as Methanosarcinales and Thermococcales (Fig. 3), was probably related to methodological implications. The 16S rRNA gene PCR-based surveys are biased,

343 as only the most abundant lineages with very similar matching priming sites are detected 344 (Teske and Sørensen, 2008). Thus, the several DNA extractions followed by pooling and concentration of several PCR and nested PCR products (increasing sensitivity), combined to the use of a primer (A344f) containing degeneracies (Teske and Sørensen, 2008), may reduce stochastic PCR biases and facilitate the detection of these rare deep sub-seafloor 348 lineages.

Thermococcales. Although sites MD06-3018 and MD06-3019 were geographically close (< $100 \mathrm{~km}$ ), they showed drastic differences in lithology and archaeal diversity. The MD06-3018 sediments were mainly characterized by a homogeneous distribution of carbonate clay and a high diversity of archaeal lineages commonly found in marine sediments, in contrast with the MD06-3019 sediments which were characterized by a heterogeneous distribution of sand and clay and a very specific archaeal diversity. Although the in-situ sediment temperatures at all sites were in a range between 2 to $3^{\circ} \mathrm{C}$ (Foucher et al., 2006), the low archaeal diversity, retrieved from the DGGE and clone library analysis of MD06-3019 sediments below $1.5 \mathrm{mbsf}$

357 (Fig 3, S2), was exclusively dominated by Thermococcales, a putative (hyper) thermophilic 
Roussel et al.

Archaeal communities in subseafloor sediments

358

359

360

361

362

363

364

365

366

367

368

369

370

371

372

373

374

375

376

377

378

379

380

381

382 383 2002).

384 A distinct Thermococcus cluster was detected at site MD06-3028, grouping with sequences 385

Euryarchaeota commonly found at hydrothermal vent sites and representing an excellent indicator of subseafloor ecosystems (Kelley et al., 2002). These sequences were shown to form a unique cluster (Fig. 7), named Thermococcales Group 1 (TG-1), within the genera Thermococcus. TG-1 16S rRNA gene sequences contain a high GC content (66\%), and were related to sequences retrieved from sulphide rich hydrothermal environments (Summit and Baross, 2001). Sequences affiliated to putative Thermococcales have been previously detected in other cold $\left(1-12^{\circ} \mathrm{C}\right)$ deep marine sediments (Inagaki et al., 2001; Kormas et al., 2003; Inagaki et al., 2006a). Their occurrence was usually interpreted as a deposition resulting from fluid migration, or as buried microbial relicts, representing "fossil DNA" (Inagaki et al., 2001; Kormas et al., 2003; Inagaki et al., 2006a). Even though the minimum temperature required for the growth of a Thermococcus is $40^{\circ} \mathrm{C}$ (Miroshnichenko et al., 2001), Thermococcales can survive over long periods in cold $\left(4^{\circ} \mathrm{C}\right)$, oxygenated samples (Jannasch et al., 1992), possibly allowing a wide dissemination in marine environments. Interestingly, a reverse-transcribed and PCR-amplified rRNA fragment related to the Thermococcales order was detected from site MD06-3019 at 0.6 mbsf by CM-DGGE and was correlated with the occurrence of an authigenic mineral (aragonite), indicating the presence of probably viable Thermococcales at this depth (see supplementary material, Fig. S6). All the sequences affiliated to the Thermococcales order found at MD06-3019 grouped in a unique cluster (TG-1), therefore suggesting an identical origin (Fig. 7). Recently, an extensive active alkaline hydrothermal field was revealed in the south-west lagoon of New Caledonia (Pelletier et al., 2006). As the MD06-3019 site shows no signs of fluid migration and as it is located in a canyon deriving substantial amounts of terrigenous matter from the lagoon, we suggest that the TG-1 could have rafted from New-Caledonia on biotic or terrigenous substrates (Thiel and Gutow, 2005; Thiel and Haye, 2006), progressively becoming less active as organic matter became recalcitrant with burial (Wellsbury et al.,

retrieved from deep hot subseafloor sediments (Roussel et al., 2008); for that reason, it was 
Roussel et al.

386 387 388 389 390 391 392 393 394 395 396 397 398 399 400 401 402 403 404 405 406 407 408 409 410

named Deep Sub-Seafloor Thermococcales Group (DSSTG). Yet, the Thermococcales detected were characterized by a probably low activity as no rRNA phylotypes were detected by RT-PCR. However, the DSSTG Archaea were only detected at this strongly faulted openocean site (MD06-3028, Fig. S1), whereas absent at the non-faulted adjacent reference site MD06-3027, suggesting that these communities could have been introduced by a vertical fluid migration.

In conclusion, the deep marine sediment archaeal distribution clearly differs from the seawater and depends on spatial and geochemical variables as previously shown (Parkes et al., 2005; Fry et al., 2006; Sørensen and Teske, 2006). This study also shows the transition between active surface archaeal communities, a component of which is probably capable of ammonium oxidation and less active deep typical sub-seafloor lineages possibly related to the methane cycle. Moreover, the occurrence of putative thermophiles in cold marine sediments suggests a possible dispersion of these typical hydrothermal archaeal communities.

\section{Experimental Procedures}

\section{Site description and sampling}

Six piston cores (MD06-3018, MD06-3019, MD06-3022, MD06-3026, MD06-3027, and MD06-3028) were collected from the New Caledonia and Fairway basins (Fig. 1) during Marion Dufresne Cruise ZoNéCo 12 in 2006, using a Calypso piston corer. Site MD06-3018 $\left(23^{\circ} 00.19^{\prime} \mathrm{S}, 166^{\circ} 08.97^{\prime} \mathrm{E} ; 2470\right.$ meters water depth; core length $\left.24.96 \mathrm{~m}\right)$, located on the New Caledonian Basin $50 \mathrm{~km}$ off the New Caledonia coast, is mainly in an open-ocean context (Foucher et al., 2006). Site MD06-3019 (22³0.64'S, 165¹1.75’E; 3522 meters water depth; core length $36.25 \mathrm{~m}$ ), $80 \mathrm{~km}$ off the coast, is located in a canyon deriving a substantial amount of terrigenous matter (Foucher et al., 2006). Sites MD06-3022 (23¹2.11'S, $163^{\circ} 27.94^{\prime} \mathrm{E} ; 2294$ meters water depth; core length $\left.8.43 \mathrm{~m}\right)$, MD06-3026 (2356.26'S, $163^{\circ} 27.72$ 'E; 2717 meters water depth; core length $\left.9.40 \mathrm{~m}\right)$, MD06-3027 (2440.61'S, $163^{\circ} 36.14^{\prime} \mathrm{E} ; 2720$ meters water depth; core length $\left.5.22 \mathrm{~m}\right)$, and MD06-3028 (24%4.20'S, 
Roussel et al.

Archaeal communities in subseafloor sediments

$413163^{\circ} 36.95^{\prime} \mathrm{E} ; 2716$ meters water depth; core length $8.03 \mathrm{~m}$ ) are located in an open-ocean

414 context in the Fairway Basin.

415 The cores were aseptically sub-sampled on board, every $20 \mathrm{~cm}$ on the first $100 \mathrm{~cm}$, and then 416 every $150 \mathrm{~cm}$, using $5 \mathrm{~mL}$ syringes (luer end removed). The samples were then immediately 417 stored anaerobically at $-80^{\circ} \mathrm{C}$ for molecular analysis and at $4{ }^{\circ} \mathrm{C}$ for prokaryotic enumeration 418 and for enrichment cultures.

419 As a contamination control, seawater from the water column was collected (MD06-CTD2; $42024^{\circ} 45.22^{\prime} \mathrm{S}, 163^{\circ} 36.95^{\prime} \mathrm{E}, 2690$ meters water depth) using a CTD rosette and immediately 421 stored at $-80^{\circ} \mathrm{C}$.

422

423

424

425

426

427

428

429

430

431

432

433

434

435

436

437

438

\section{Total prokaryotic cell enumeration}

Total prokaryotic counts were determined, with an epifluorescence microscope (BX60, Olympus ${ }^{\mathrm{TM}}$ ), by acridine orange staining, on subsamples stored at $4^{\circ} \mathrm{C}$ under anaerobic conditions in the dark (<5 days), as previously described (Cragg et al., 2000).

\section{Mineralogical composition of sediments}

The mineralogy of 8 sediment samples from cores MD06-3018 and MD06-3019 was determined by X-ray diffraction (XRD) analysis using a Bruker D8 Advance equipped with a Cu X Ray tube and a Vantec detector. Samples were not dried before analysis and diffraction patterns were obtained between 5 and 70 degrees. Mineral determination and semiquantitative estimations were performed with the EUA program.

\section{Geochemical analysis}

Methane analyses were performed on cores MD06-3019, MD06-3022, MD06-3026, MD063027 and MD06-3028, at the end of each core segment (1.5 m long), using the headspace technique. The cores were immediately sub-sampled on board using $5 \mathrm{~mL}$ syringes (luer end removed) and added to headspace vials (20 mL) filled with a $\mathrm{NaCl} / \mathrm{HgCl}_{2}$ work solution. Methane concentrations were determined using a HP 7694 automatic headspace sampler connected to a HP 5890 gas chromatograph equipped with FID and TCD detectors. The 2- 
439 sigma uncertainty is better than $4 \%$ (Donval et al., unpublished). Results are expressed as 440 microlitre per litre of sediment $(\mu \mathrm{L} / \mathrm{L})$.

441 Pore-waters were extracted on board from MD06-3019 and MD06-3022 cores from the end 442 of each core segment by centrifuging sediment samples (10000 rpm over $30 \mathrm{~min}$ ). The 443 dissolved anions $\left(\mathrm{SO}_{4}{ }^{2-}, \mathrm{Cl}^{-}\right)$and cations $\left(\mathrm{Na}^{+}, \mathrm{Ca}^{2+}, \mathrm{Mg}^{2+}\right)$ were determined from diluted 444 pore-waters using a Dionex DX100 ion chromatograph. The IAPSO standard seawater was 445 used for calibration and quality control. Results are expressed as millimole per litre pore446 water (mM).

DNA extractions and PCR amplification

448 To avoid contaminations, all manipulations were carried out in a PCR cabinet exclusively 449 dedicated to the present study (Biocap ${ }^{\mathrm{TM}}$ RNA/DNA, erlab ${ }^{\circledR}$ ), using Biopur ${ }^{\circledR} 1.5 \mathrm{~mL}$ Safe-Lock 450 micro test tubes (Eppendorf ${ }^{\mathrm{TM}}$ ), Rnase/Dnase Free Water (MP Biomedicals ${ }^{\mathrm{TM}}$ ) and UV451 treated (>60 $\mathrm{min}$ ) plasticware and pipettes.

452 DNA was extracted, pooled and purified from $5 \times 1 \mathrm{~g}$ uncontaminated frozen sample following 453 a modified FastDNA ${ }^{\circledR}$ Spin Kit for Soil (Bio101 Systems, MP Biomedicals ${ }^{\mathrm{TM}}$ ) protocol 454 (Webster et al., 2003; Roussel et al., 2009).

455 All amplifications were performed using a "GeneAmp PCR system" 9700 ${ }^{\circledR}$ (Applied 456 Biosystems $\left.{ }^{\mathrm{TM}}\right)$. All PCR mixtures $(50 \mu \mathrm{L})$ contained $5 \mu \mathrm{L}$ of DNA template, $1 \mathrm{X}$ Taq DNA 457 polymerase buffer (MP Biomedicals ${ }^{\mathrm{TM}}$ ), $1 \mu \mathrm{L}$ of dNTP (10 mM of each dATP, dCTP, dGTP 458 and dTTP), $10 \mu \mathrm{M}$ of each primer and $0.5 \mu \mathrm{L}$ of Taq DNA polymerase (MP Biomedicals ${ }^{\mathrm{TM}}$ ). 459 Negative controls were also carried out with DNA extractions performed with no sample. For 460 all controls, no PCR products were detected.

461 Archaeal 16S rRNA gene amplification was conducted by nested PCR with combination of 462 primers A8f (5'-CGG TTG ATC CTG CCG GA-3') and A1492r (5'-GGC TAC CTT GTT ACG 463 ACT T-3') in the first round (Teske et al., 2002; Lepage et al., 2004), and with A344f (5'-AYG 464 GGG YGC ASC AGG SG-3') and A915r (5'-GTG CTC CCC CGC CAA TTC CT-3') in the 465 second round (Stahl and Amann, 1991; Sørensen et al., 2004). PCR cycles for the first round 
Roussel et al.

Archaeal communities in subseafloor sediments

466

467

468

469

470

471

472

473

474

475

476

477

478

479

480

481

482

483

484

485

486

487

488

489

490

491

(A8f/A1492r), and for the second round (A344f/A915r) were as previously described (Roussel et al., 2009). To minimize stochastic PCR bias, five independent PCR products from the first round were pooled and purified (QIAquick PCR purification Kit; Qiagen ${ }^{\mathrm{TM}}$ ) and used as template for the second round. This nested PCR was necessary to obtain visible PCR products on a $0.8 \%(\mathrm{w} / \mathrm{v})$ agarose gel stained with ethidium bromide.

A portion of the amoA gene (635 bp) was amplified with primers Arch-amoAF and ArchamoAR (Francis et al., 2005), and the following reaction conditions were performed: 1 cycle of $5 \mathrm{~min}$ at $95^{\circ} \mathrm{C}, 35$ cycles of $45 \mathrm{~s}$ at $94^{\circ} \mathrm{C}, 60 \mathrm{~s}$ at $53^{\circ} \mathrm{C}$ and $60 \mathrm{~s}$ at $72^{\circ} \mathrm{C}$, and 1 cycle of 15 $\min$ at $72^{\circ} \mathrm{C}$.

\section{RNA extractions and RT-PCR amplification}

Total RNA was extracted from each uncontaminated frozen sample $(5 \times 1 \mathrm{~g})$ using the FastRNA $^{\circledR}$ Pro soil direct Kit (Bio101 Systems, MP Biomedicals ${ }^{\mathrm{TM}}$ ) as previously described (Roussel et al., 2009), with the following modifications: the addition of $170 \mu \mathrm{g}$ poly-adenylic acid, tubes kept on ice and extended spin. After bead-beating on a FastPrep FP120 homogenizer (Bio101 Systems, MP Biomedicals ${ }^{\mathrm{TM}}$ ), the $3 / 4$ of the aqueous phases were transferred to a new tube before the remaining aqueous phases were homogenized a second time. After the addition of $660 \mu \mathrm{L}$ of isopropanol (100\%), the tubes were incubated 60 $\min$ at $-20^{\circ} \mathrm{C}$ followed by centrifugation at $20000 \times \mathrm{g}$ for $15 \mathrm{~min}$ at $1^{\circ} \mathrm{C}$. In order to increase the RNA yield, the extraction procedure was ended after the first ethanol wash and diluted in $100 \mu \mathrm{L}$ of DEPC water.

To digest trace amounts of DNA, the extraction products were immediately pooled and 150 $\mu \mathrm{L}$ were incubated 1 hour at $37^{\circ} \mathrm{C}$ with $1 \mathrm{X}$ of TURBO DNase ${ }^{\circledR}$ buffer and $18 \mathrm{U}$ of TURBO DNase $^{\circledR}$ (Ambion ${ }^{\mathrm{TM}}$ ). The digestion was stopped by adding EDTA to a final concentration of $15 \mathrm{mM}$ and heating $10 \mathrm{~min}$ at $65^{\circ} \mathrm{C}$. The product was finally concentrated and purified with the RNeasy minikit (Qiagen ${ }^{\mathrm{TM}}$ ), following manufacturer's instructions, to give a final volume of $100 \mu \mathrm{L}$. 
Roussel et al.

492 The purified RNA product was immediately serially diluted ( 1 to 50 times) and reverse 493 transcribed using the OneStep RT-PCR kit (Qiagen ${ }^{\mathrm{TM}}$ ), according to the manufacturer's 494 instructions, with combination of $16 \mathrm{~S}$ rRNA primers for Archaea with A8f-A1492r and the 495 following touchdown PCR protocol as previously described (Roussel et al., 2009). To obtain 496 visible products, a nested PCR was performed as described for the 16S rRNA gene 497 amplification. Nested PCR assays, using the 16S rRNA primers for Archaea, without the 498 reverse transcribed step, showed no DNA contamination.

\section{DGGE analysis}

500 In order to obtain the general archaeal 16S rRNA gene depth diversity, a PCR-DGGE 501 analysis was performed. To avoid background interference, visualization of unspecific 502 fragments, and to increase sensitivity and resolution, nested PCR was performed as 503 described for the archaeal 16S rRNA gene amplification using a Cy3 labelled reverse primer 504 Saf-PARCH $519 r^{\star}$ Cy3 or A344f $\mathrm{f}^{\mathrm{GC}}-\mathrm{A} 915 \mathrm{r}^{\star}$ Cy3. All manipulations were performed in the dark. 505 The touchdown PCR protocol was as previously described (Casamayor et al., 2000; Nicol et 506 al., 2003). The PCR products were analyzed by DGGE using a DCode Universal Mutation 507 Detection System ${ }^{\circledR}\left(\right.$ BioRad $\left.^{\mathrm{TM}}\right)$ on a $1 \mathrm{~mm}$ thick $(16 \times 16 \mathrm{~cm})$ polyacrylamide gel 508 (acrylamide/bisacrylamide, 40\%, 37,5:1, BioRad ${ }^{\mathrm{TM}}$ ) prepared with $1 \times$ TAE buffer $(\mathrm{pH}$ 8, $50940 \mathrm{mM}$ de Tris Base, $20 \mathrm{mM}$ acetic acid, 1 mM d'EDTA, MP Biomedicals ${ }^{\mathrm{TM}}$ ) and poured with 510 a "Gradient maker" (Hoefer SG30 ${ }^{\circledR}$ ). For Saf-PARCH 519r*Cy3 PCR products, the 8\% (w/v) 511 polyacrylamide gel had a denaturant gradient between 30 and $60 \%$. For $A 344 f^{\mathrm{GC}}-\mathrm{A} 915 \mathrm{r}^{*} \mathrm{Cy} 3$ 512 PCR products, the $6 \%(\mathrm{w} / \mathrm{v})$ polyacrylamide gel had a denaturant gradient between 40 and $51370 \%$. Electrophoresis was carried in $1 \times \operatorname{TAE}$ buffer at $60^{\circ} \mathrm{C}$ for 330 min at $200 \mathrm{~V}$ (initially at $51480 \mathrm{~V}$ for $10 \mathrm{~min})$. The gel was scanned using a Phospho fluorimager Typhoon $9400^{\circledR}$ 515 (Amersham Biosciences ${ }^{\mathrm{TM}}$ ). Prior to band excision as described previously (Wilms et al., 516 2006), the gel was stained with SYBRGold ${ }^{\circledR}$ nucleic acid gel stain for $20 \mathrm{~min}$, and washed for 51710 min with $1 \times$ TAE buffer and visualized with a Dark Reader transilluminator (Clare 518 Chemicals, Dolores, CO). The DGGE profiles were analyzed by cluster analysis using the 
Roussel et al.

Archaeal communities in subseafloor sediments

519

520

521

522

523

524

525

526

527

528

529

530

531

532

533

534

535

536

537

538

539

540

541

542

543 Chimeras (Cole et al., 2003) were excluded from the clone libraries and a total of 771

544 sequences (including those from the 16S rRNA gene and amoA gene) were used for further

software package GelCompar II version 5.10 (Applied Maths, St-Martens-Latem, Belgium) as described elsewhere (Wilms et al., 2006).

\section{Co-Migration-DGGE analysis (CM-DGGE)}

Co-Migration-DGGE analysis (CM-DGGE), a new approach based on DGGE was developed in order to obtain the general archaeal depth diversity and associated active fraction. After amplification of the PCR products, using two different fluorescent reverse labelled primers from either total DNA or cDNA of the same sample, these were pooled and loaded into the

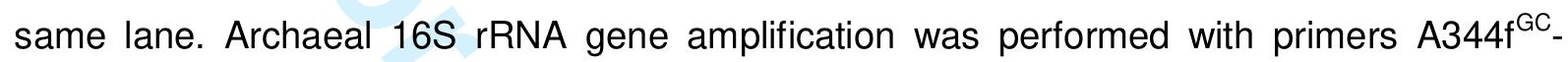
A915r or Saf-PARCH 519r, labelled with either Cy3 or Cy5, following touchdown PCR protocol as previously described (Casamayor et al., 2000; Nicol et al., 2003). The DGGE analysis and gel conditions were the same as described for the DGGE analysis, except that loading and migration were performed in the dark. The gel was scanned using a Phospho fluorimager Typhoon $9400^{\circledR}$ (Amersham Biosciences ${ }^{\mathrm{TM}}$ ).

\section{Cloning and sequencing}

According to archaeal DGGE profiles, 21 DNA-derived 16SrRNA gene, two RNA-derived 16S rRNA gene and two DNA-derived amoA gene clone libraries were constructed. To minimize stochastic PCR bias (Polz and Cavanaugh, 1998), five independent PCR products were pooled, purified (QIAquick PCR purification Kit; Qiagen ${ }^{\mathrm{TM}}$ ), and cloned into Escherichia coli (XL10-Gold; Stratagene ${ }^{\mathrm{TM}}$ ) using the pGEM-T Easy vector system I (Promega ${ }^{\mathrm{TM}}$ ) following the manufacturer's instructions. Positive transformants were screened by PCR amplification of the insert using the vector-specific M13 primers. Plasmid extraction, purification and sequencing of the insert, were carried out by the sequencing OuestGenepole platform ${ }^{\circledR}$ of Roscoff Marine laboratory (France).

\section{Phylogenetic analysis}


Roussel et al.

Archaeal communities in subseafloor sediments

545 phylogenetic analysis. The phylogenetic placement was carried out using NCBI BLAST 546 search program within GenBank (http://www.ncbi.nlm.nih.gov/blast) (Altschul et al., 1990). 547 The 16S rRNA sequences ( $\sim 53$ bases) were then edited in the BioEdit 7.0.5.3 program 548 (Hall, 1999) and aligned using CLUSTALW (Thompson et al., 1994). The phylogenetic trees 549 were constructed by the PHYLO_WIN program (Galtier et al., 1996) with neighbour-joining 550 method (Saitou and Nei, 1987) and Jukes and Cantor correction. The Thermococcales 551 dataset was further analyzed by Bayesian method. Bayesian trees were inferred using 552 MrBayes 3.1.2. (Huelsenbeck and Ronquist, 2001). The Markov Chain Monte Carlo search 553 was run with 4 chains for 2000000 generations, with trees being sampled every 100 554 generations. Stabilization of the chain parameters (tree likelihood, a shape parameter, and 555 proportion of invariant sites) was verified with the program ModelTest version 3.7.2 (Posada 556 and Crandall, 1998). The first 5000 trees were discarded (burn-in), keeping only trees 557 generated after those parameters stabilized. Phylogenetic trees were viewed using the 558 program TreeDyn (Chevenet et al., 2006). The nonchimeric amoA sequences ( 635 bases) 559 560 were translated into amino acids using BioEdit and then aligned using CLUSTALW, and the PHYLO_WIN program with neighbour-joining algorithm and PAM distance (Dayhoff et al., 1978) was then used for phylogenetic tree construction. For the 16S rRNA and amoA 562 phylogenetic reconstruction, the robustness of inferred topology was tested by bootstrap 563 resampling (1000), values over $50 \%$ are shown on the trees. The richness from the clone 564 libraries was estimated, with the rarefaction curves at $99 \%, 97 \%$ and $95 \%$ sequence identity 565 levels, using the DOTUR program (Schloss and Handelsman, 2005). Operational taxonomic 566 units (OTUs), using a $97 \%$ sequence similarity, were generated with the SON program 567 (Schloss and Handelsman, 2006), and the percentage of coverage (Cx) of the clone libraries 568 was calculated by Good's method (Good, 1953) as described by Singleton and colleagues 569 (Singleton et al., 2001). Statistical estimators, the significance of population differentiation 570 among clone libraries $\left(F_{S T}\right)$ (Martin, 2002), and the exact tests of population genetic 571 differentiation (Raymond and Rousset, 1995), were calculated using Arlequin 3.11 (Excoffier 572 et al., 2005). 
Roussel et al.

Archaeal communities in subseafloor sediments

573

574

575

576

577

578

579

580

581

582

583

584

585

586

587

588

589

590

591

592

593

594

595

596

597

598

599

600

601

602

603

604

\section{Nucleotide sequence accession numbers}

The sequences are available from GenBank database under the following accession numbers and names: 16S rRNA gene and rRNA (AM989356 to AM989452) and amoA gene (AM988840 to AM988859).

\section{Acknowledgements}

The authors are deeply indebted to Yvon Balut, chief of the operation on board the R.V. Marion Dufresne and to the I.P.E.V. (Institut Paul Emile Victor). We also thank Jean-Paul Foucher, chief scientist of ZoNéCo 12. All of the crew and the Scientific Party were crucial in this effort, especially Laetitia Hervé for the sampling efforts, and Frauke Klingelhoefer and Emmanuelle Cosquer for kindly providing the bathymetric map and seismic profiles. We are much indebted to anonymous referees for their helpful comments. This work was supported by the Université de Bretagne Occidentale, the Centre National de la Recherche Scientifique and the Région Bretagne. We are also grateful to Ouest-Génopole for the use of their facilities. Erwan Roussel was supported by a grant from the Ministère de la Recherche.

\section{References}

Altschul, S.F., Gish, W., Miller, W., Myers, E.W., and Lipman, D.J. (1990) Basic local alignment search tool. J Mol Biol 215: 403-410.

Auzende, J.M., Van de Beuque, S., Dickens, G., Francois, C., Lavoy, Y., Voutay, O., and Exon, N. (2000) Deep sea diapirs and bottom simulating reflector in Fairway Basin (SW Pacific). Marine Geophysical Researches 21: 579-587.

Biddle, J.F., Fitz-Gibbon, S., Schuster, S.C., Brenchley, J.E., and House, C.H. (2008) Metagenomic signatures of the Peru Margin subseafloor biosphere show a genetically distinct environment. Proc Natl Acad Sci U S A 105: 10583-10588.

Biddle, J.F., Lipp, J.S., Lever, M.A., Lloyd, K.G., Sørensen, K.B., Anderson, R. et al. (2006) Heterotrophic Archaea dominate sedimentary subsurface ecosystems off Peru. Proc Natl Acad Sci U S A 103: 3846-3851.

Bidle, K.A., Kastner, M., and Bartlett, D.H. (1999) A phylogenetic analysis of microbial communities associated with methane hydrate containing marine fluids and sediments in the Cascadia margin (ODP site 892B). FEMS Microbiol Lett 177: 101-108.

Boetius, A., Ravenschlag, K., Schubert, C.J., Rickert, D., Widdel, F., Gieseke, A. et al. (2000) A marine microbial consortium apparently mediating anaerobic oxidation of methane. Nature 407: 623-626. 
605 Brochier-Armanet, C., Boussau, B., Gribaldo, S., and Forterre, P. (2008) Mesophilic 606 Crenarchaeota: proposal for a third archaeal phylum, the Thaumarchaeota. Nat Rev 607 Microbiol 6: 245-252.

608 Casamayor, E.O., Schafer, H., Baneras, L., Pedros-Alio, C., and Muyzer, G. (2000) 609 Identification of and spatio-temporal differences between microbial assemblages from two 610 neighboring sulfurous lakes: comparison by microscopy and denaturing gradient gel 611 electrophoresis. Appl Environ Microbiol 66: 499-508.

612 Chevenet, F., Brun, C., Banuls, A.L., Jacq, B., and Christen, R. (2006) TreeDyn: towards 613 dynamic graphics and annotations for analyses of trees. BMC Bioinformatics 7: 439.

614 Cole, J.R., Chai, B., Marsh, T.L., Farris, R.J., Wang, Q., Kulam, S.A. et al. (2003) The 615 Ribosomal Database Project (RDP-II): previewing a new autoaligner that allows regular 616 updates and the new prokaryotic taxonomy. Nucleic Acids Res 31: 442-443.

617 Cragg, B.A., Summit, M., and Parkes, R.J. (2000) Bacterial profiles in a sulfide mound (Site 618 1035) and an area of active fluid venting (Site 1036) in hot hydrothermal sediments from 619 Middle Valley (Northeast Pacific). In Proceedings of the Ocean Drilling Program, Scientific 620 Results 169. TX, United States: Texas A \& M University, Ocean Drilling Program, College 621 Station p. 18.

622 D'Hondt, S., Rutherford, S., and Spivack, A.J. (2002) Metabolic activity of subsurface life in 623 deep-sea sediments. Science 295: 2067-2070.

Damste, J.S.S., and Coolen, M.J.L. (2006) Fossil DNA in cretaceous black shales: myth or reality? Astrobiology 6: 299-302.

Danovaro, R., Dell'anno, A., Pusceddu, A., and Fabiano, M. (1999) Nucleic acid concentrations (DNA, RNA) in the continental and deep-sea sediments of the eastern Mediterranean: relationships with seasonally varying organic inputs and bacterial dynamics. Deep-Sea Research Part I-Oceanographic Research Papers 46: 1077-1094.

Dayhoff, M.O., Schwartz, R.M., and Orcutt, B.C. (1978) A model of evolutionary change in proteins. In Atlas of Protein Sequences and Structure. Dayhoff, M.O. (ed). Washington DC: National Biomedical Research Foundation, pp. 345-352.

Dell'Anno, A., and Corinaldesi, C. (2004) Degradation and turnover of extracellular DNA in marine sediments: ecological and methodological considerations. Appl Environ Microbiol 70: 4384-4386.

Dell'Anno, A., and Danovaro, R. (2005) Extracellular DNA plays a key role in deep-sea ecosystem functioning. Science 309: 2179.

640 Dell'Anno, A., Fabiano, M., Duineveld, G.C.A., Kok, A., and Danovaro, R. (1998) Nucleic acid 641 (DNA, RNA) quantification and RNA/DNA ratio determination in marine sediments: 642 comparison of spectrophotometric, fluorometric, and HighPerformance liquid 643 chromatography methods and estimation of detrital DNA. Appl Environ Microbiol 64: 32386443245. sulfide- and sulfur-rich spring. Appl Environ Microbiol 70: 2230-2239. 
Excoffier, L., Laval, G., and Schneider, S. (2005) Arlequin ver. 3.0: An integrated software package for population genetics data analysis. Evol Bioinform Online 1: 47-50.

Foucher, J.P., Charlou, J.L., Harmegnies, F., Wirrmann, D., Sémah, A.M., Chaduteau, C., and Roussel, E. (2006) Rapport des travaux de la campagne ZoNéCo 12 : Campagne AUSFAIR/ZoNéCo12 à bord du N/O Marion Dufresne (12 au 26 février 2006). In: IFREMER.

Francis, C.A., Roberts, K.J., Beman, J.M., Santoro, A.E., and Oakley, B.B. (2005) Ubiquity and diversity of ammonia-oxidizing Archaea in water columns and sediments of the ocean. Proc Natl Acad Sci U S A 102: 14683-14688.

Froelich, P.N., Klinkhammer, G.P., Bender, M.L., Luedtke, N.A., Heath, G.R., Cullen, D. et al. (1979) Early oxidation of organic-matter in pelagic sediments of the eastern equatorial atlantic-suboxic diagenesis. Geochim Cosmochim Acta 43: 1075-1090.

Fry, J.C., Webster, G., Cragg, B.A., Weightman, A.J., and Parkes, R.J. (2006) Analysis of DGGE profiles to explore the relationship between prokaryotic community composition and biogeochemical processes in deep subseafloor sediments from the Peru Margin. FEMS Microbiol Ecol 58: 86-98.

Fry, J.C., Parkes, R.J., Cragg, B.A., Weightman, A.J., and Webster, G. (2008) Prokaryotic biodiversity and activity in the deep subseafloor biosphere. FEMS Microbiol Ecol 66: 181196.

Galtier, N., Gouy, M., and Gautier, C. (1996) SEAVIEW and PHYLO_WIN: two graphic tools for sequence alignment and molecular phylogeny. Comput Appl Biosci 12: 543-548.

Good, I.J. (1953) The population frequencies of species and the estimation of population parameters. Biometrika 40: 237-264.

Hall, T.A. (1999) BioEdit: a user-friendly biological sequence alignment editor and analysis program for Windows 95/98/NT. Nucleic Acids Symp Ser 41: 95-98.

Hallam, S.J., Mincer, T.J., Schleper, C., Preston, C.M., Roberts, K., Richardson, P.M., and DeLong, E.F. (2006) Pathways of carbon assimilation and ammonia oxidation suggested by environmental genomic analyses of marine Crenarchaeota. PLOS Biol 4: 520-536.

Hinrichs, K.U., Hayes, J.M., Sylva, S.P., Brewer, P.G., and DeLong, E.F. (1999) Methaneconsuming Archaebacteria in marine sediments. Nature 398: 802-805.

Huelsenbeck, J.P., and Ronquist, F. (2001) MRBAYES: Bayesian inference of phylogenetic trees. Bioinformatics 17: 754-755.

Inagaki, F., Takai, K., Komatsu, T., Kanamatsu, T., Fujioka, K., and Horikoshi, K. (2001) Archaeology of Archaea: geomicrobiological record of Pleistocene thermal events concealed in a deep-sea subseafloor environment. Extremophiles 5: 385-392.

Inagaki, F., Suzuki, M., Takai, K., Oida, H., Sakamoto, T., Aoki, K. et al. (2003) Microbial communities associated with geological horizons in coastal subseafloor sediments from the sea of Okhotsk. Appl Environ Microbiol 69: 7224-7235.

Inagaki, F., Nunoura, T., Nakagawa, S., Teske, A., Lever, M., Lauer, A. et al. (2006a) Biogeographical distribution and diversity of microbes in methane hydrate-bearing deep marine sediments on the Pacific Ocean Margin. Proc Natl Acad Sci U S A 103: 2815-2820. 
688

689

690

691

692

693

694

695

696

697

698

699

700

701

702

703

704

705

706

707

708

709

710

711

712

713

714

715

716

717

718

719

720

721

722

723

724

725

726

727

Inagaki, F., Kuypers, M.M., Tsunogai, U., Ishibashi, J., Nakamura, K., Treude, T. et al. (2006b) Microbial community in a sediment-hosted $\mathrm{CO}_{2}$ lake of the southern Okinawa Trough hydrothermal system. Proc Natl Acad Sci U S A 103: 14164-14169.

Jannasch, H.W., Wirsen, C.O., Molyneaux, S.J., and Langworthy, T.A. (1992) Comparative physiological-studies on hyperthermophilic Archaea isolated from deep-sea hot vents with emphasis on Pyrococcus strain Gb-D. Appl Environ Microbiol 58: 3472-3481.

Kelley, D.S., Baross, J.A., and Delaney, J.R. (2002) Volcanoes, fluids, and life at mid-ocean ridge spreading centers. Annu Rev Earth Planet Sci 30: 385-491.

Kemp, P.F., Lee, S., and Laroche, J. (1993) Estimating the growth rate of slowly growing marine bacteria from RNA content. Appl Environ Microbiol 59: 2594-2601.

Kerkhof, L., and Ward, B.B. (1993) Comparison of nucleic acid hybridization and fluorometry for measurement of the relationship between RNA/DNA ratio and growth rate in a marine bacterium. Appl Environ Microbiol 59: 1303-1309.

Könneke, M., Bernhard, A.E., de la Torre, J.R., Walker, C.B., Waterbury, J.B., and Stahl, D.A. (2005) Isolation of an autotrophic ammonia-oxidizing marine archaeon. Nature 437: 543-546.

Kormas, K.A., Smith, D.C., Edgcomb, V., and Teske, A. (2003) Molecular analysis of deep subsurface microbial communities in Nankai Trough sediments (ODP Leg 190, Site 1176). FEMS Microbiol Ecol 45: 115-125.

Kramer, J.G., and Singleton, F.L. (1993) Measurement of rRNA variations in natural communities of microorganisms on the southeastern U.S. continental shelf. Appl Environ Microbiol 59: 2430-2436.

Lepage, E., Marguet, E., Geslin, C., Matte-Tailliez, O., Zillig, W., Forterre, P., and Tailliez, P. (2004) Molecular diversity of new Thermococcales isolates from a single area of hydrothermal deep-sea vents as revealed by randomly amplified polymorphic DNA fingerprinting and 16S rRNA gene sequence analysis. Appl Environ Microbiol 70: 1277-1286.

Lipp, J.S., Morono, Y., Inagaki, F., and Hinrichs, K.-U. (2008) Significant contribution of Archaea to extant biomass in marine subsurface sediments. Nature. 454: 991-994.

Lloyd, K.G., Lapham, L., and Teske, A. (2006) An anaerobic methane-oxidizing community of ANME-1b Archaea in hypersaline Gulf of Mexico sediments. Appl Environ Microbiol 72: 7218-7230.

Martin, A.P. (2002) Phylogenetic approaches for describing and comparing the diversity of microbial communities. Appl Environ Microbio/ 68: 3673-3682.

Miroshnichenko, M.L., Hippe, H., Stackebrandt, E., Kostrikina, N.A., Chernyh, N.A., Jeanthon, C. et al. (2001) Isolation and characterization of Thermococcus sibiricus sp nov from a Western Siberia high-temperature oil reservoir. Extremophiles 5: 85-91.

Muyzer, G. (1999) DGGE/TGGE a method for identifying genes from natural ecosystems. Curr Opin Microbiol 2: 317-322.

Muyzer, G., and Stams, A.J.M. (2008) The ecology and biotechnology of sulphate-reducing bacteria. Nat Rev Microbiol 6: 441-454. 
Myers, R., Sheffield, V. and Cox, D. (1988) Detection of single base changes in DNA: ribonuclease cleavage and denaturing gradient gel electrophoresis. In Genome Analysis. A Practical Approach. Davies, K. (ed). Oxford: IRL Press, pp. 95-139.

731

732

733

734

735

736

737

738

739

740

741

742

743

744

745

746

747

748

749

750

751

752

753

754

755

756

757

758

759

760

761

762

763

764

765

766

767

768

769

Neufeld, J.D., and Mohn, W.W. (2005) Fluorophore-labeled primers improve the sensitivity, versatility, and normalization of denaturing gradient gel electrophoresis. Appl Environ Microbiol 71: 4893-4896.

Newberry, C.J., Webster, G., Cragg, B.A., Parkes, J.R., Weighthman, A.J., and Fry, J.C. (2004) Diversity of prokaryotes and methanogenesis in deep subsurface sediments from Nankai Trough, ODP Leg 190. Environ Microbiol 6: 274-287.

Nicol, G.W., Glover, L.A., and Prosser, J.I. (2003) The impact of grassland management on archaeal community structure in upland pasture rhizosphere soil. Environ Microbiol 5: 152162.

Parkes, R.J., Cragg, B.A., and Wellsbury, P. (2000) Recent studies on bacterial populations and processes in subfloor sediments: A review. Hydrogeology Journal 8: 11-28.

Parkes, R.J., Webster, G., Cragg, B.A., Weightman, A.J., Newberry, C.J., Ferdelman, T.G. et al. (2005) Deep sub-seafloor prokaryotes stimulated at interfaces over geological time. Nature 436: 390-394.

Pelletier, B., Chevillon, C., Menou, J.L., Butscher, J., Folcher, E., Geoffray, C. et al. (2006) Plongées, forage et cartographie Baie du Prony et Banc Gail, lagon Sud de NouvelleCalédonié, N.O.ALIS, 13-17 juin 2005 et cartographie Baie du Prony N.O.ALIS, 25-26 septembre 2005. In Rapport de missions, Sci. Terre, Geol-Geophys. Nouméa: Nouméa IRD, p. 44.

Polz, M.F., and Cavanaugh, C.M. (1998) Bias in template-to-product ratios in multitemplate PCR. Appl Environ Microbiol 64: 3724-3730.

Posada, D., and Crandall, K.A. (1998) MODELTEST: testing the model of DNA substitution. Bioinformatics 14: 817-818.

Preston, C.M., Wu, K.Y., Molinski, T.F., and DeLong, E.F. (1996) A psychrophilic crenarchaeon inhabits a marine sponge: Cenarchaeum symbiosum gen nov, sp, nov. Proc Natl Acad Sci U S A 93: 6241-6246.

Purdy, K.J., Nedwell, D.B., and Embley, T.M. (2003) Analysis of the sulfate-reducing bacterial and methanogenic archaeal populations in contrasting Antarctic sediments. Appl Environ Microbiol 69: 3181-3191.

Purdy, K.J., Munson, M.A., Nedwell, D.B., and Embley, T.M. (2002) Comparison of the molecular diversity of the methanogenic community at the brackish and marine ends of a UK estuary. FEMS Microbiol Ecol 39: 17-21.

Raymond, M., and Rousset, F. (1995) An exact test for population differentiation. Evolution 49: $1280-1283$.

Roussel, E.G., Bonavita, M.-A.C., Querellou, J., Cragg, B.A., Webster, G., Prieur, D., and Parkes, R.J. (2008) Extending the sub-sea-floor biosphere. Science 320: 1046.

Roussel, E.G., Sauvadet, A.-L., Allard, J., Chaduteau, C., Richard, P., Cambon Bonavita, M.A., and Chaumillon, E. (2009) Archaeal methane cycling communities associated with gassy subsurface sediments of Marennes-Oléron Bay (France). Geomicrobiol J 26: 31-43. 
770

771

772

773

774

775

776

777

778

779

780

781

782

783

784

785

786

787

788

789

790

791

792

793

794

795

796

797

798

799

800

801

802

803

804

805

806

807

808 809

810

811

Saitou, N., and Nei, M. (1987) The neighbor-joining method: a new method for reconstructing phylogenetic trees. Mol Biol Evol 4: 406-425.

Schippers, A., Neretin, L.N., Kallmeyer, J., Ferdelman, T.G., Cragg, B.A., John Parkes, R., and Jorgensen, B.B. (2005) Prokaryotic cells of the deep sub-seafloor biosphere identified as living bacteria. Nature 433: 861-864.

Schloss, P.D., and Handelsman, J. (2004) Status of the microbial census. Microbiol Mol Biol Rev 68: 686-691.

Schloss, P.D., and Handelsman, J. (2005) Introducing DOTUR, a computer program for defining operational taxonomic units and estimating species richness. Appl Environ Microbiol 71: 1501-1506.

Schloss, P.D., and Handelsman, J. (2006) Introducing SONS, a tool for operational taxonomic unit-based comparisons of microbial community memberships and structures. Appl Environ Microbiol 72: 6773-6779.

Sheffield, V.C., Cox, D.R., Lerman, L.S., and Myers, R.M. (1989) Attachment of a 40-basepair $\mathrm{G}+\mathrm{C}$-rich sequence (GC-clamp) to genomic DNA fragments by the polymerase chain reaction results in improved detection of single-base changes. Proc Natl Acad Sci U S A 86: 232-236.

Singh, N., Kendall, M.M., Liu, Y.T., and Boone, D.R. (2005) Isolation and characterization of methylotrophic methanogens from anoxic marine sediments in Skan Bay, Alaska: description of Methanococcoides alaskense sp nov., and emended description of Methanosarcina baltica. Int J Syst Evol Microbiol 55: 2531-2538.

Singleton, D.R., Furlong, M.A., Rathbun, S.L., and Whitman, W.B. (2001) Quantitative comparisons of 16S rRNA gene sequence libraries from environmental samples. Appl Environ Microbiol 67: 4374-4376.

Sivan, O., Schrag, D.P., and Murray, R.W. (2007) Rates of methanogenesis and methanotrophy in deep-sea sediments. Geobiology 5: 141-151.

Smalla, K., Oros-Sichler, M., Milling, A., Heuer, H., Baumgarte, S., Becker, R. et al. (2007) Bacterial diversity of soils assessed by DGGE, T-RFLP and SSCP fingerprints of PCRamplified 16S rRNA gene fragments: Do the different methods provide similar results? $J$ Microbiol Methods 69: 470-479.

Sørensen, K.B., and Teske, A. (2006) Stratified communities of active Archaea in deep marine subsurface sediments. Appl Environ Microbiol 72: 4596-4603.

Sørensen, K.B., Lauer, A., and Teske, A. (2004) Archaeal phylotypes in a metal-rich and lowactivity deep subsurface sediment of the Peru Basin, ODP Leg 201, Site 1231. Geobiology 2: 151-161.

Stahl, D.A., and Amann, R.I. (1991) Development and application of nucleic acid probes in bacterial systematics. In Nucleic Acid Techniques in Bacterial Systematics. Stackebrandt, E., and Goodfellow, M. (eds). Chichester: John Wiley and Sons, pp. 205-248.

Summit, M., and Baross, J.A. (2001) A novel microbial habitat in the mid-ocean ridge subseafloor. Proc Natl Acad Sci U S A 98: 2158-2163.

Suzuki, M.T., and Giovannoni, S.J. (1996) Bias caused by template annealing in the amplification of mixtures of 16S rRNA genes by PCR. Appl Environ Microbiol 62: 625-630. 
Takai, K., and Horikoshi, K. (1999) Genetic diversity of Archaea in deep-sea hydrothermal vent environments. Genetics 152: 1285-1297.

Teske, A., and Sørensen, K.B. (2008) Uncultured Archaea in deep marine subsurface sediments: have we caught them all? ISME J 2: 3-18.

Teske, A., Hinrichs, K.U., Edgcomb, V., de Vera Gomez, A., Kysela, D., Sylva, S.P. et al. (2002) Microbial diversity of hydrothermal sediments in the Guaymas Basin: evidence for anaerobic methanotrophic communities. Appl Environ Microbiol 68: 1994-2007.

Thiel, M., and Gutow, L. (2005) The ecology of rafting in the marine environment - I - The floating substrata. In Oceanography and Marine Biology: An Annual Review, Vol 42, pp. 181263.

Thiel, M., and Haye, P.A. (2006) The ecology of rafting in the marine environment. III. Biogeographical and evolutionary consequences. In Oceanography and Marine Biology - an Annual Review, Vol 44, pp. 323-429.

Thompson, J.D., Higgins, D.G., and Gibson, T.J. (1994) CLUSTAL W: improving the sensitivity of progressive multiple sequence alignment through sequence weighting, positionspecific gap penalties and weight matrix choice. Nucleic Acids Res 22: 4673-4680.

Treude, T., Kruger, M., Boetius, A., and Jorgensen, B.B. (2005) Environmental control on anaerobic oxidation of methane in the gassy sediments of Eckernforde Bay (German Baltic). Limnol Oceanogr 50: 1771-1786.

Valentine, D.L. (2007) Adaptations to energy stress dictate the ecology and evolution of the Archaea. Nat Rev Microbiol 5: 316-323.

von Wintzingerode, F., Gobel, U.B., and Stackebrandt, E. (1997) Determination of microbial diversity in environmental samples: pitfalls of PCR-based rRNA analysis. FEMS Microbiol Rev 21: 213-229.

Webster, G., Newberry, C.J., Fry, J.C., and Weightman, A.J. (2003) Assessment of bacterial community structure in the deep sub-seafloor biosphere by $16 \mathrm{~S}$ rDNA-based techniques: a cautionary tale. J Microbiol Methods 55: 155-164.

Webster, G., Blazejak, A., Cragg, B.A., Schippers, A., Sass, H., Rinna, J. et al. (2008) Subsurface microbiology and biogeochemistry of a deep, cold-water carbonate mound from the Porcupine Seabight (IODP Expedition 307). Environ Microbiol 11: 239-257.

Wellsbury, P., Mather, I., and Parkes, R.J. (2002) Geomicrobiology of deep, low organic carbon sediments in the Woodlark Basin, Pacific Ocean. FEMS Microbiol Ecol 42: 59-70.

Whitman, W.B., Coleman, D.C., and Wiebe, W.J. (1998) Prokaryotes: The unseen majority. Proc Natl Acad Sci U S A 95: 6578-6583.

Wilms, R., Kopke, B., Sass, H., Chang, T.S., Cypionka, H., and Engelen, B. (2006) Deep biosphere-related bacteria within the subsurface of tidal flat sediments. Environ Microbiol 8: 709-719. 
Roussel et al.

Archaeal communities in subseafloor sediments

850

851

852

853

854

855

856

857

858

859

860

861

862

863

864

865

866

867

868

869

870

871

872

873

874

875

876

877

\section{Captions}

Fig. 1. Bathymetric map of the location of ZoNéCo 12 sites. The white arrow represents substantial amounts of terrigenous matter derived from New Caledonia.

Fig. 2. Geochemical and total prokaryote cell depth profiles of the sediments from the Fairway and New Caledonia Basin sites.

Fig. 3. Depth distribution of the archaeal phylogenetic community structures based on $16 \mathrm{~S}$ rRNA gene from the Fairway and New Caledonia Basin sites. According to archaeal DGGE profiles (DGGE), clone libraries were only constructed for the depths with the most representative archaeal phylogenetic distribution for each core. The phylogenetic affiliation of each clone sequence was determined by similarity analysis. The relative abundance of each phylotype was calculated and represented in a column diagram. The percentage of coverage of each clone library examined is indicated in brackets. The asterisks indicate groups of clone libraries with insignificant $(P<0.01)$ differences between all the diversity indices $\left(F_{S T}\right.$ and the exact test method). ANME-2: anaerobic methane oxidizers group 2, NMG-1: Novel Methanosarcinales group 1, SAGMEG: South African Gold Mine Euryarchaeotic Group, DHVE6: Deep-Sea Hydrothermal Vent Euryarchaeotal Group 6.

Fig. 4. Phylogenetic tree representing the Marine Group 1 (MG-1) $16 \mathrm{~S}$ rRNA gene sequences DNA- and RNA-derived. Each phylotype from each clone library is represented by one sequence with $\geq 97 \%$ similarity grouping. The tree was constructed using the neighbour-joining method with Jukes and Cantor correction. Bootstrap values $<50 \%$ are not shown. Sequences are color-coded according to site location. Sequences from RNA-derived clone libraries were underlined.

Fig. 5. Co-migration denaturant gradient gel electrophoresis (CM-DGGE) analysis of archaeal 16S rRNA genes DNA-derived (blue) and RNA-derived (red) from MD06-3018 and MD06-3019 sites. The numbered bands were excised and sequenced. The lineage and the sequence similarity of the closest match by BLASTN search are given on the right. PCR products were amplified with the Saf-PARCH $519 r^{*}$ Cy5 (blue) or Saf-PARCH $519 r^{\star}$ Cy3 (red) primer set and electrophoresis was performed using a gradient of 30-60\% denaturant. 
Roussel et al.

Archaeal communities in subseafloor sediments

878 Fig. 6. Phylogenetic tree based on translated, partial amino acid sequences of amo $A$ gene 879 (<212 amino acids). The tree was constructed using the neighbour-joining method using 880 PAM distance (Dayhoff et al., 1978). The robustness of inferred topology was tested by the 881 bootstrap. Bootstrap values $<50 \%$ are not shown. Sequences are color-coded according to 882 location (blue, sediment; red, seawater; brown, soil) and were clustered as previously 883 published (Francis et al., 2005). Sequences retrieved from the New Caledonia Basin are in 884 black.

885 886 887 888 889

890 Group 1, DSSTG: Deep Sub-Seafloor Thermococcales Group. Sequences are color-coded 891 according to the clone library.

\section{Supplementary material}

893 Fig. S1. Seismic profiles of the Fairway Basin with the location of each site: MD06-3022, 894 MD06-3026, MD06-3027 and MD06-3028. Figure modified from Foucher et al. (2006).

895

896

Fig. S2. Denaturant gradient gel electrophoresis (DGGE) analysis of archaeal $16 \mathrm{~S}$ rRNA 897 genes of the cores from the Fairway and New Caledonia Basin sites. The numbered bands 898 were excised and sequenced. The lineage and the sequence similarity of the closest match 899 by BLASTN search are given on the right. (A) PCR products were amplified with the A344f ${ }^{\mathrm{GC}}$. 900 A915r primer set and electrophoresis was performed using a gradient of $40-70 \%$ denaturant. 901 (B) PCR products were amplified with the Saf-PARCH 519r primer set and electrophoresis 902 was performed using a gradient of $30-60 \%$ denaturant. (C) Cluster analysis of DGGE band 903 patterns. The dendrogram was calculated by Pearson correlation and UPGMA. 
904 Fig. S3. Rarefaction curves for the 16S rRNA gene clone libraries from the Fairway and New 905 Caledonia Basin sites (Schloss and Handelsman, 2005). The sequence identity levels are 906 represented in brackets.

907 Fig. S4. Phylogenetic tree representing the Euryarchaeota 16S rRNA gene, except the 908 Thermococcales lineage, sequences DNA- and RNA derived. RNA-derived sequences are 909 underlined. Each phylotype is represented by one sequence with $\geq 97 \%$ similarity grouping. 910 The tree was constructed using the neighbour-joining method with Jukes and Cantor 911 correction. Bootstrap values $<50 \%$ are not shown. ANME: anaerobic methane oxidizers, 912 NMG-1: Novel Methanosarcinales group 1, SAGMEG: South African Gold Mine 913 Euryarchaeotic Group, DHVE6: Deep-Sea Hydrothermal Vent Euryarchaeotal Group 6, 914 MBG-D: Marine Benthic Group D, MG: Marine Groups. Sequences are color-coded 915 according to site location.

916 Fig. S5. Phylogenetic tree representing the Crenarchaeota 16S rRNA gene sequences, 917 except the MG-1 lineage, DNA- and RNA derived. RNA-derived sequences are underlined. 918 Each phylotype is represented by one sequence with $\geq 97 \%$ similarity grouping. The tree was 919 constructed using the neighbour-joining method with Jukes and Cantor correction. Bootstrap 920 values <50\% are not shown. MCG: Miscellaneous Crenarchaeotal Group, MBG-B: Marine 921 Benthic Group B, MBG-A: Marine Benthic Group A. Sequences are color-coded according to 922 site location.

923 Fig. S6. Co-Migration Denaturant Gradient Gel Electrophoresis (CM-DGGE) analysis of 924 archaeal 16S rRNA genes DNA-derived (blue) and RNA-derived (red) from the cores at 925 MD06-3018 and MD06-3019 sites. The numbered bands were excised and sequenced. The 926 lineage and the sequence similarity of the closest match by BLASTN search are given on the 927 right. PCR products were amplified with the $\mathrm{A} 344 \mathrm{f}^{\mathrm{GC}}-\mathrm{A} 915 r^{*} \mathrm{Cy} 5$ (blue) or $\mathrm{A} 344 \mathrm{f}^{\mathrm{GC}}-\mathrm{A} 915 r^{*} \mathrm{Cy} 3$ 928 (red) primer set and electrophoresis was performed using a gradient of $40-70 \%$ denaturant. 929 (A) DNA-derived $\left(A 344 f^{\mathrm{GC}}-\mathrm{A} 915 r^{*} \mathrm{Cy} 5\right)$. (B) RNA-derived $\left(\mathrm{A} 344 \mathrm{f}^{\mathrm{GC}}-\mathrm{A} 915 \mathrm{r}^{*} \mathrm{Cy} 3\right)$. (C) both DNA- and RNA-derived. 
Roussel et al.

Archaeal communities in subseafloor sediments

932 


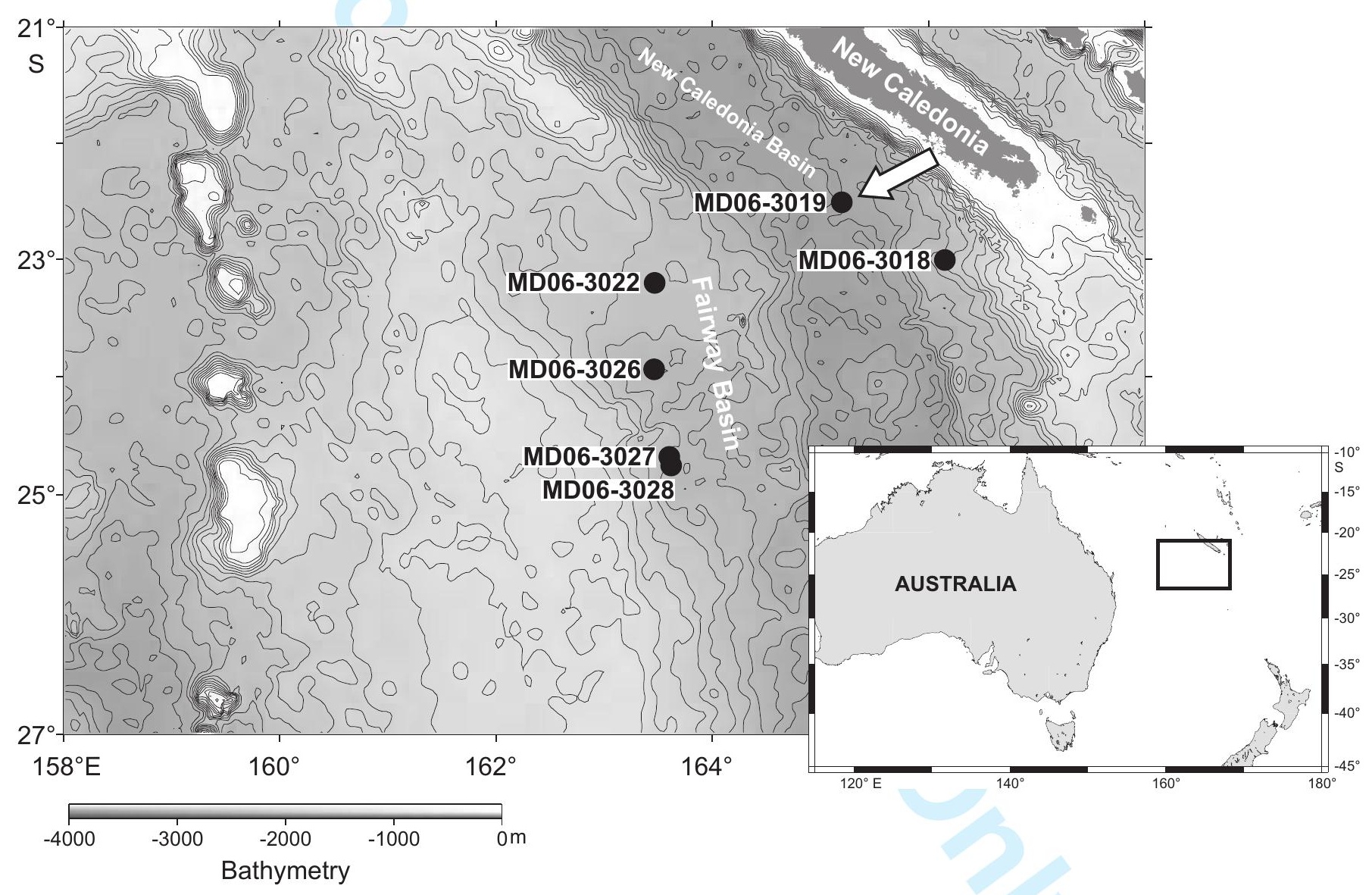




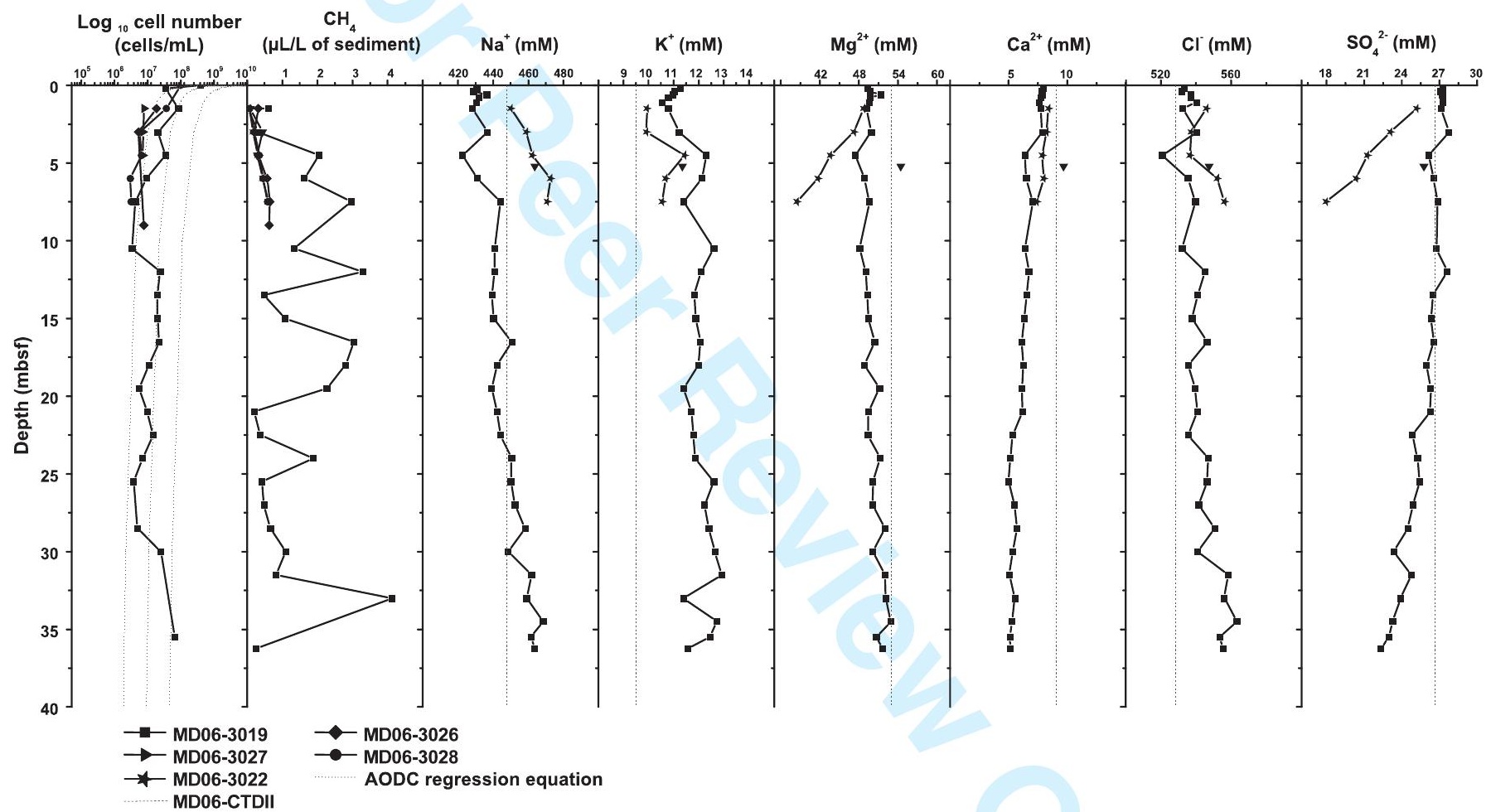




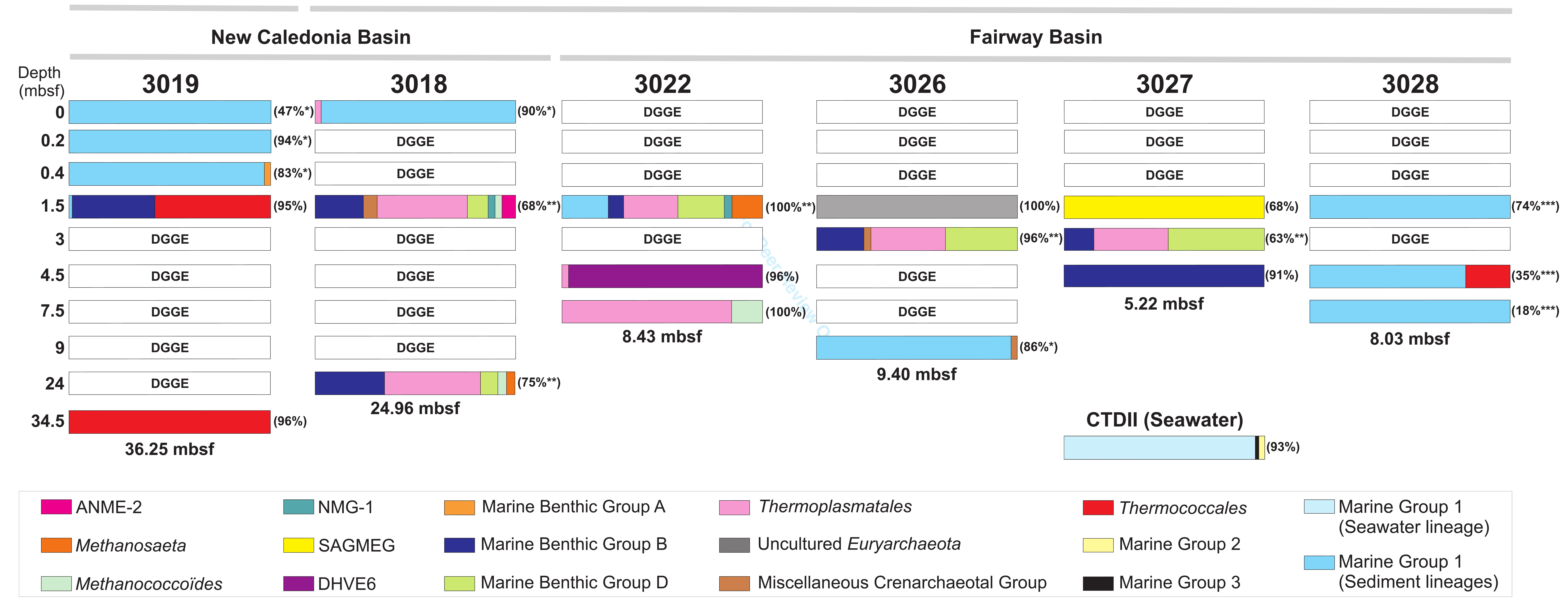




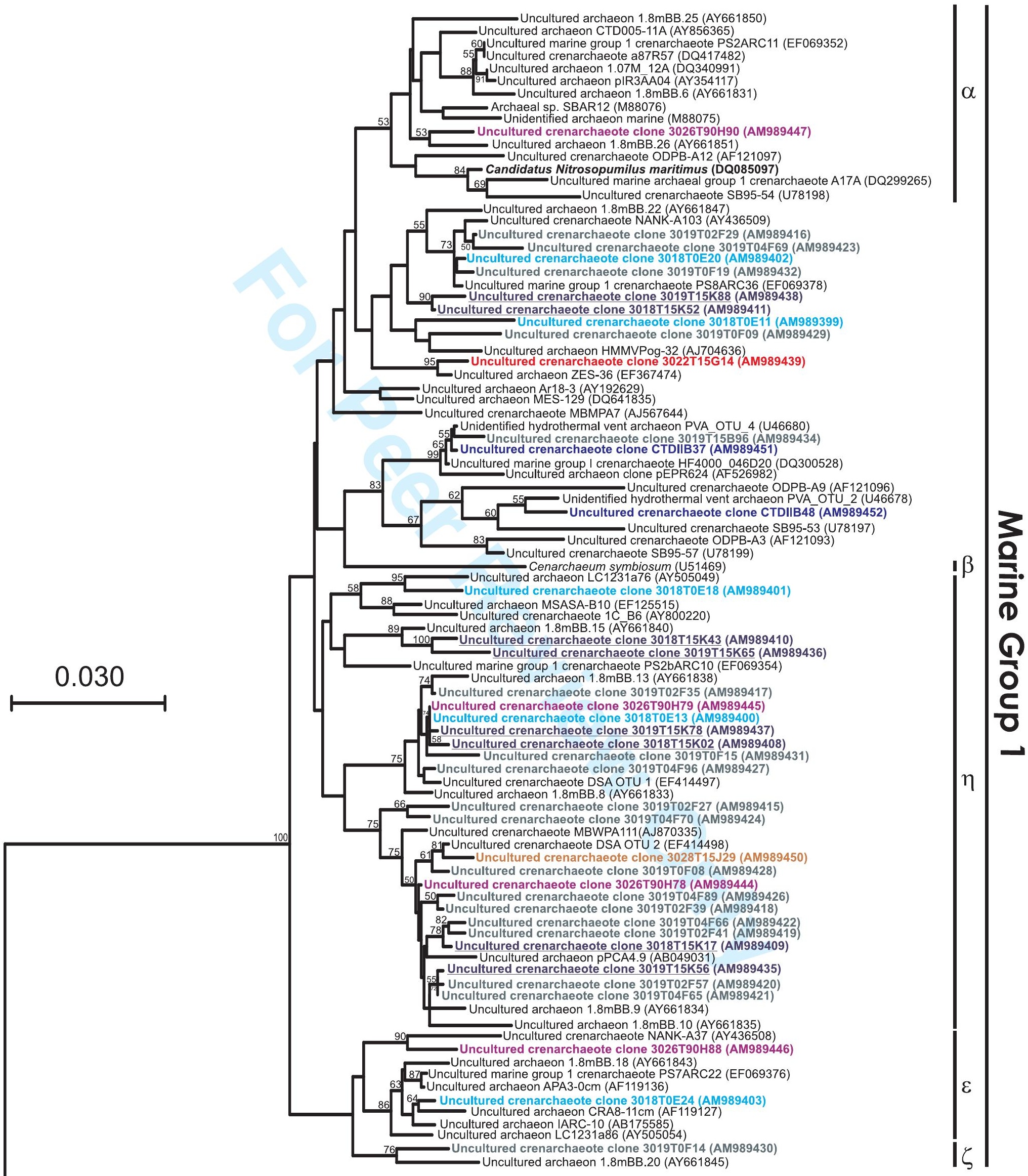





1 MG-1 (Unc. crenarchaeote clone aEPR13S145 - EU259329 - 90\%)

2 MG-1 (Unc. crenarchaeote clone aEPR13S145 - EU259329 - 96\%)

3 MG-1 (Unc. crenarchaeote clone 1.8mBB.9 - AY661834 - 92\%)

4 MG-1 (Unc. crenarchaeote clone MD2902-A18 - EU048603 - 89\%)

5 MG-1 (Unc. crenarchaeote clone arc3. - AJ783668 - 89\%)

6 MBG-B (Unc. crenarchaeote clone MD2896-0.1m.4 - DQ984881-100\%) 
Uncultured archaeon, hydrothermal sediment: p763_AMO_1.02. (AB305359) Uncultured crenarchaeote, sediment: ES HL 14 (DQ148̄810) Uncultured crenarchaeote, sediment: ES HL 16 (DQ148812)

Uncultured crenarchaeote, sediment: $\mathrm{E} \bar{S} \mathrm{H}-{ }_{-} 17$ (DQ148813)

LUncultured crenarchaeote, sediment: S7-A-15 (EU025154)

- Uncultured crenarchaeote amoA 3019T15SAm004 (AM988840)

Uncultured crenarchaeote amoA 3019T15SAm009 (AM988846) Uncultured crenarchaeote amoA 3019T15SAm010 (AM988847)
Uncultured crenarchaeote amoA 3019T15SAm023 (AM988853)

Uncultured crenarchaeote, sediment: SF CB20 4 (DQ148659)

Uncultured crenarchaeote, sediment: ES_HL_11 (DQ148807) Uncultured crenarchaeote, sediment: $\mathrm{M} X-6$ 21 (DQ148621)

- Uncultured crenarchaeote, sediment: S33-A-10 (EU025182) - Uncultured crenarchaeote amoA 3019T15SAm025 (AM988855) Uncultured crenarchaeote amoA 3019T15SAm031 (AM988857)

-Uncultured crenarchaeote, sediment: ES HL 4 (DQ148800)

Uncultured crenarchaeote, sediment: HB_B_0604_B08 (EU022953)

-Uncultured crenarchaeote, hydrothermal sediment: p763_AMO_4.27. (AB305363) Uncultured crenarchaeote amoA 3019T15SAm006 (AM988843) Uncultured crenarchaeote amoA 3019T15SAm018 (AM988850) Uncultured crenarchaeote amoA 3018T15SAm001 (AM988841) Uncultured crenarchaeote amoA 3019T15SAm027 (AM988856) Uncultured crenarchaeote amoA 3019T15SAm036 (AM988858) Uncultured crenarchaeote amoA 3018T15SAm002 (AM988842) Uncultured crenarchaeote amoA 3019T15SAm037 (AM988859) Uncultured crenarchaeote amoA 3019T15SAm007 (AM988844) Uncultured crenarchaeote amoA 3019T15SAm020(AM988851) Uncultured archaeon, deep-sea sediment: CBK-G3N131 (AB289370) 4 Uncultured crenarchaeote amoA 3019T15SAm014 (AM988848) Uncultured crenarchaeote amoA 3019T15SAm021 (AM988852) - Uncultured crenarchaeote amoA 3019T15SAm017 (AM988849) Uncultured crenarchaeote amoA 3019T15SAm008 (AM988845) Uncultured crenarchaeote amoA 3019T15SAm024 (AM988854)

Uncultured archaeon, coral reef sediment: checker801 (EU125514)

Uncultured crenarchaeote, sediment: S10-A-14 (EU025171)

55 Uncultured crenarchaeote, sediment: A ES HI 17 (DQ148785)

Uncultured crenarchaeote, sediment: SF NB1 6 (DQ148638)

- Uncultured crenarchaeote, sediment: $\overline{M X} 6 \overline{15}$ (DQ148615) Uncultured crenarchaeote, sediment: ES_HL_12 (DQ148808)

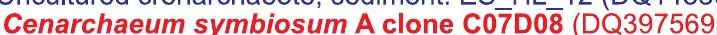

- Uncultured crenarchaeote, seawater: MB M2 40m 20 (DQ148860)

Uncultured crenarchaeote, seawater: ETNP 23 (DQ148766)

64 Uncultured crenarchaeote, seawater: MB M2_40m 22 (DQ148862) Uncultured crenarchaeote, seawater: MB C130m 9 (DQ148827) Candidatus Nitrosopumilus maritimus putative amoA (DQ085098) 78 Uncultured crenarchaeote, seawater: MB C130m_22 (DQ148840)

Uncultured crenarchaeote, seawater: ETNP 1 (DQ148744)

96-Uncultured crenarchaeote, seawater: ETNP_22 (DQ148765)

Uncultured crenarchaeote, seawater: MB_C130m_1 (DQ148819) ${ }_{00}$ Uncultured crenarchaeote, seawater: MB_C130m_10 (DQ148828) Uncultured crenarchaeote, seawater: BS15.7 19 (DQ148696)


Uncultured crenarchaeote, soil: amoA-like protein (CAF28771)
Uncultured crenarchaeote, soil: OKR-C-5 (DQ148869) Uncultured crenarchaeote, soil: OKR-C-5 (DQ148869) Uncultured crenarchaeote, sediment: ES_HL_21 (DQ148816)

\section{Soil/sediment}









\section{Supplementary material}
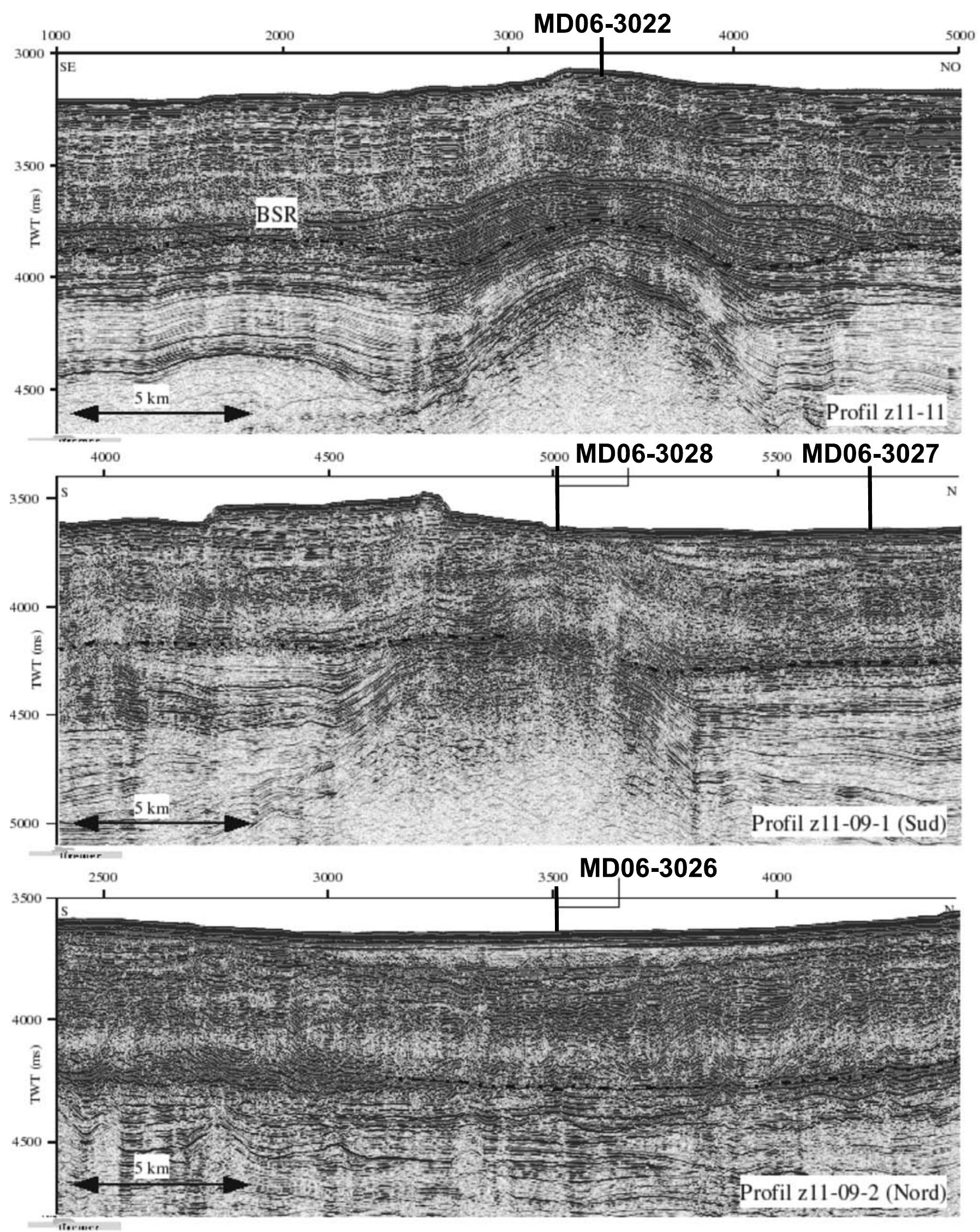

Fig. S1. Seismic profiles of the Fairway Basin on which are located the position of the sites MD06-3022, MD06-3026, MD06-3027 and MD06-3028. Figure modified from Foucher et al. (2006). 




A

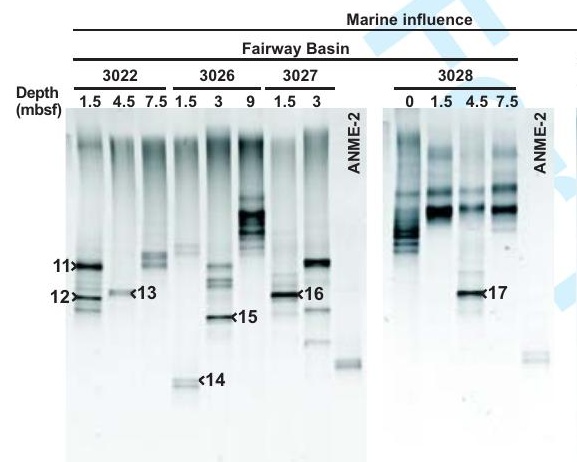

B



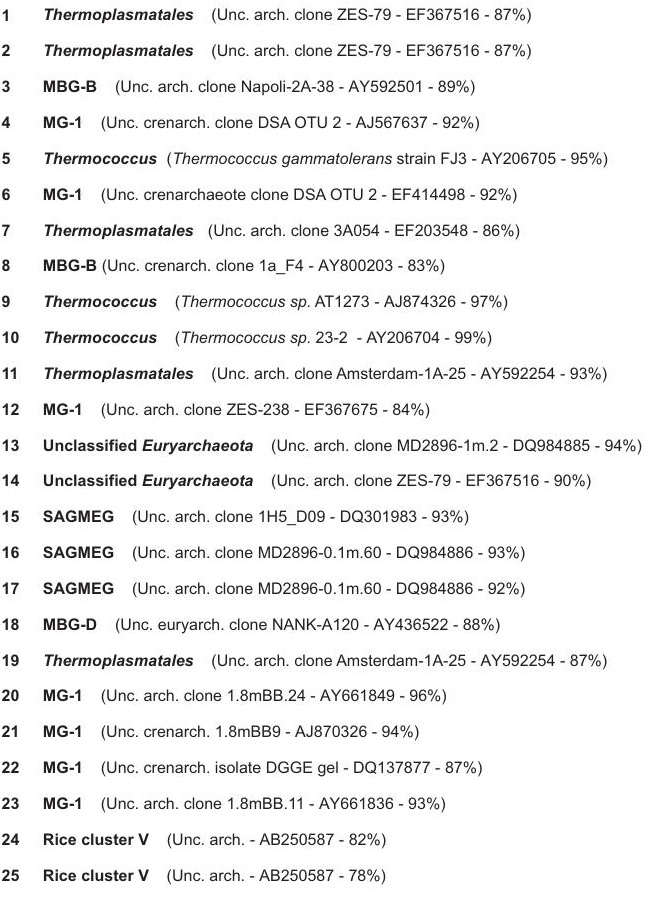$$
\text { Rice cluster V (Unc. arch. - AB250587 - 78\%) }
$$ 

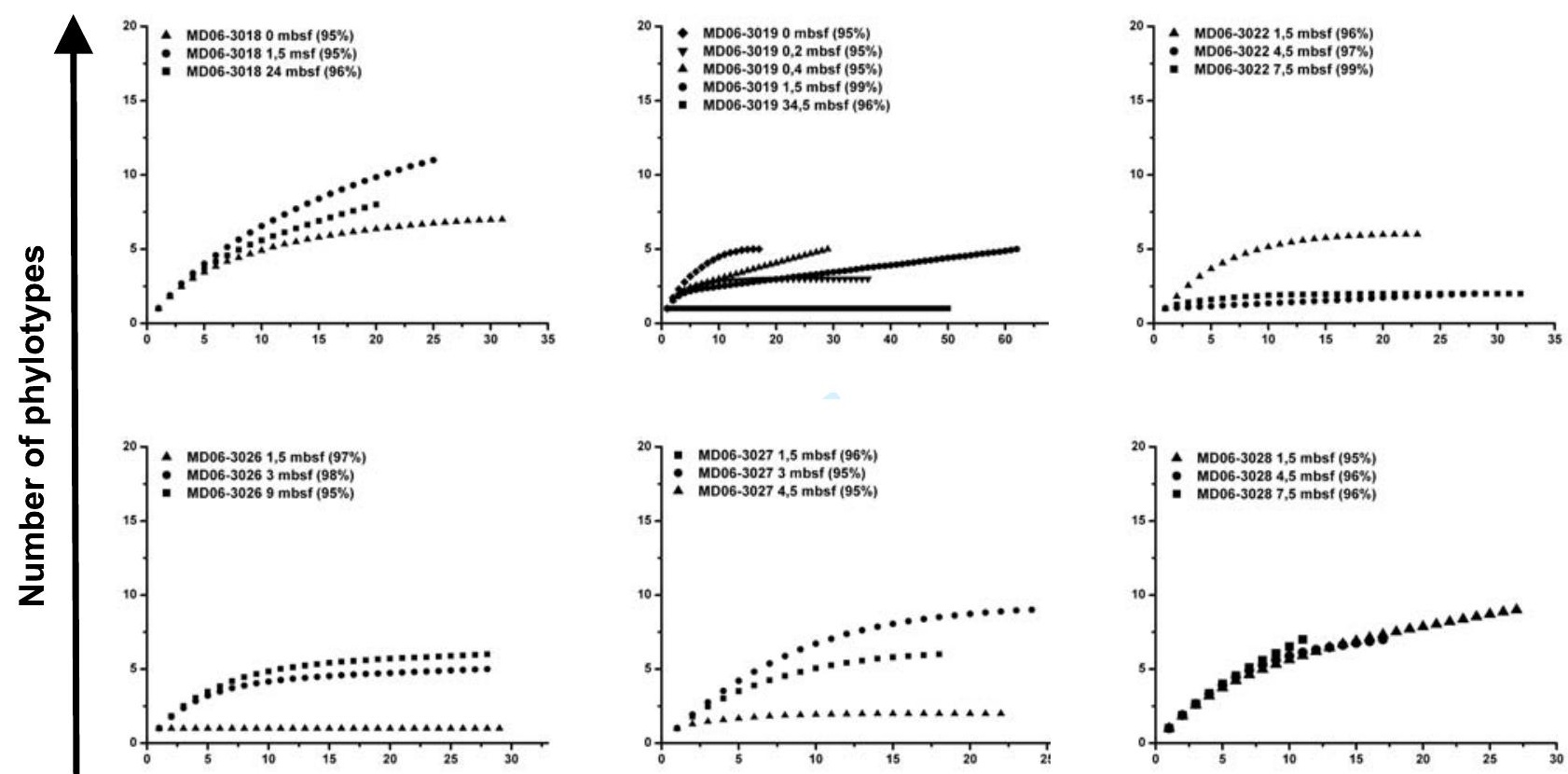

\section{Number of clones}

Fig. S3. Rarefaction curves for the $16 \mathrm{~S}$ rRNA gene clone libraries from the Fairway and New Caledonia Basin sites (Schloss and Handelsman, 2005). The sequence identity levels are represented in brackets. 




Fig. S4. Phylogenetic tree representing the Euryarchaeota $16 \mathrm{~S}$ rRNA gene, except the Thermococcales lineage, sequences DNA- and RNA derived. RNA-derived sequences are underlined. Each phylotype is represented by one sequence with $\geq 97 \%$ similarity grouping. The tree was constructed using the neighbour-joining method with Jukes and Cantor correction. Bootstrap values $<50 \%$ are not shown. ANME: anaerobic methane oxidizers, NMG-1: Novel Methanosarcinales group 1, SAGMEG: South African Gold Mine Euryarchaeotic Group, DHVE6: Deep-Sea Hydrothermal Yent Euryarchaeotal Group 6, MBG-D: Marine Benthic Group D, MG: Marine Groups. Sequences






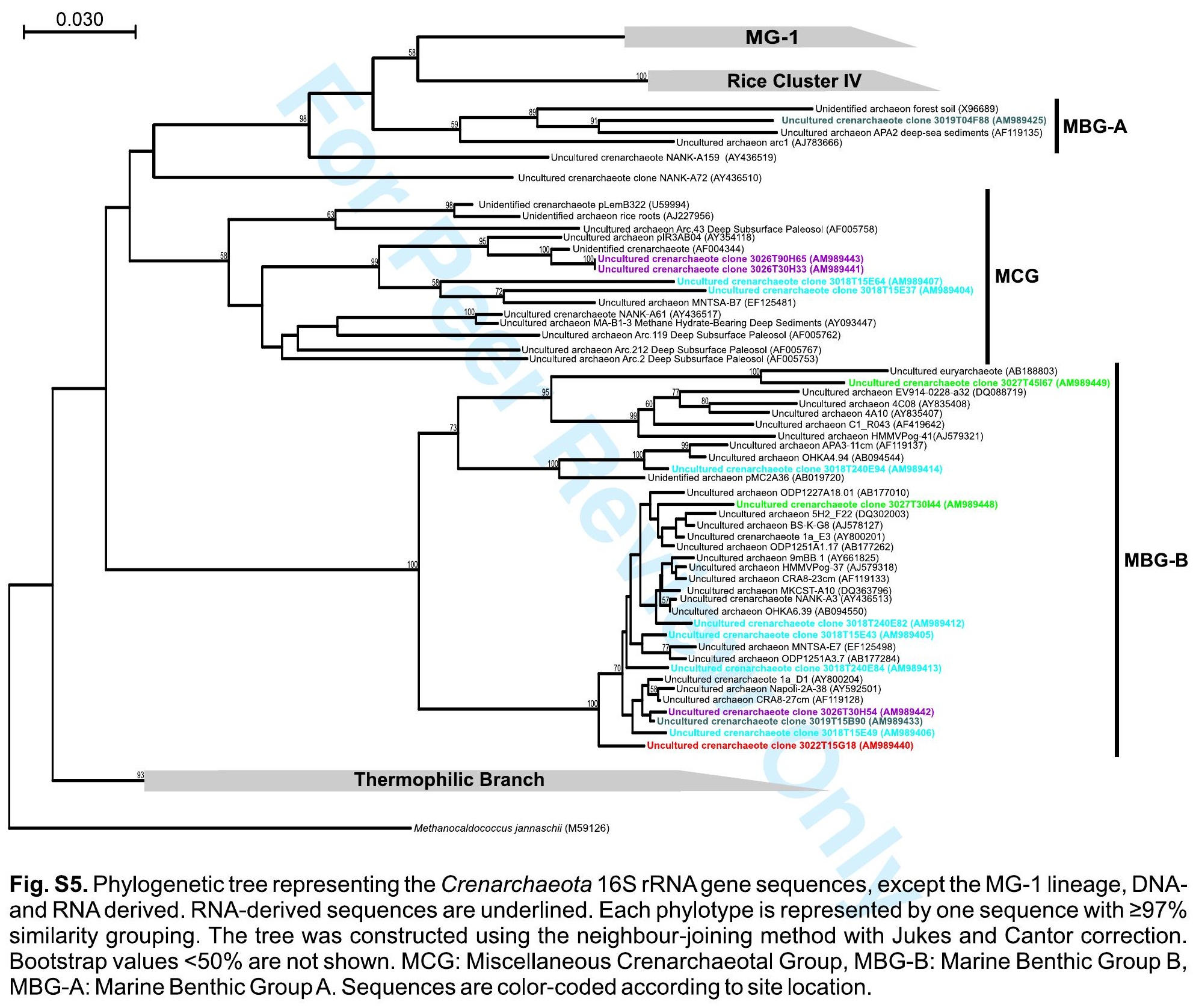



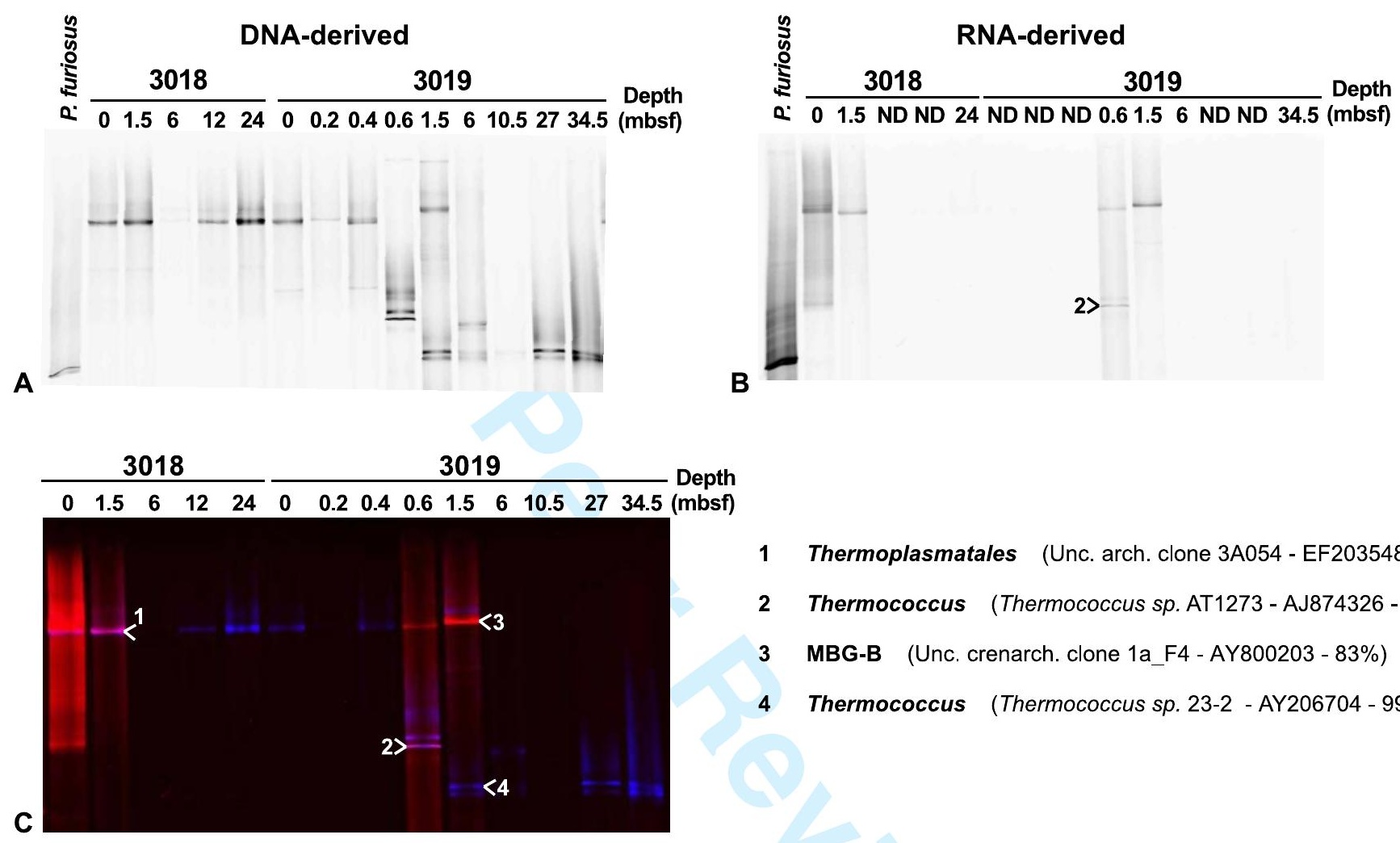

B



\footnotetext{
1 Thermoplasmatales (Unc. arch. clone 3A054-EF203548-86\%)

2 Thermococcus (Thermococcus sp. AT1273 - AJ874326 - 97\%)

3 MBG-B (Unc. crenarch. clone 1a_F4 - AY800203-83\%)

4 Thermococcus (Thermococcus sp. 23-2 - AY206704-99\%)
}

Fig. S6. Co-Migration Denaturant Gradient Gel Electrophoresis (CM-DGGE) analysis of archaeal 16S rRNA genes DNA-derived (blue) and RNA-derived (red) of the cores from MD06-3018 and MD06-3019. The numbered bands were excised and sequenced. The lineage and the sequence similarity of the closest match by BLASTN search are given on the right. PCR products were amplified with the A344fGC-A915r*Cy5 (blue) or A344fGC-A915 ${ }^{*}$ Cy3 (red) primer set and electrophoresis was performed using a gradient of $40-70 \%$ denaturant. (A) DNA-derived (A344fGC-A915 $\mathrm{r}^{\star}$ Cy5). (B) RNA-derived (A344fGC-A915 $\left.\mathrm{r}^{*} \mathrm{Cy} 3\right)$. (C) both DNAand RNA-derived. ND, not determined.

Foucher, J.P., Charlou, J.L., Harmegnies, F., Wirrmann, D., Sémah, A.M., Chaduteau, C., and Roussel, E. (2006) Rapport des travaux de la campagne ZoNéCo 12 : Campagne AUSFAIR/ZoNéCo12 à bord du N/O Marion Dufresne (12 au 26 février 2006). In: IFREMER.

Schloss, P.D., and Handelsman, J. (2005) Introducing DOTUR, a computer program for defining operational taxonomic units and estimating species richness. Appl Environ Microbiol 71: 1501-1506. 